\title{
\#USAS
}

\section{Geologic Map of the Goleta Quadrangle, Santa Barbara County, California}

by Scott A. Minor, Karl S. Kellogg, Richard G. Stanley, and Theodore R. Brandt

OPEN FILE REPORT 2007-1403

2007

Version 1.0

This report is preliminary and has not been reviewed for conformity with U.S. Geological Survey editorial standards or with the North American Stratigraphic Code. Any use of trade, firm, or product names is for descriptive purposes only and does not imply endorsement by the U.S. Government

U.S. DEPARTMENT OF THE INTERIOR

U.S. GEOLOGICAL SURVEY 


\title{
Geologic Map of the Goleta Quadrangle, Santa Barbara County, California
}

\author{
Version 1.0 \\ By \\ Scott A. Minor, Karl S. Kellogg, Richard G. Stanley, and Theodore R. Brandt \\ INTRODUCTION
}

This map depicts, at a compilation scale of 1:24,000, the distribution of bedrock units and surficial deposits and associated deformation underlying those parts of the Santa Barbara coastal plain and adjacent southern flank of the Santa Ynez Mountains within the Goleta 7 $1 / 2$ ' quadrangle (fig. 2). (The digital geologic database for this map is available on the Internet at: http://pubs.usgs.gov/of/2007/1403) The Santa Barbara coastal plain is located in the western Transverse Ranges physiographic province along an east-west-trending segment of the southern California coastline about $100 \mathrm{~km}(62 \mathrm{mi})$ northwest of Los Angeles (fig. 1). The coastal plain extends from the Santa Ynez Mountains on the north to the Santa Barbara Channel on the south, obtains a maximum width of about $5 \mathrm{~km}$ near the cities of Santa Barbara and Goleta, and narrows to $1 \mathrm{~km}$ or less several kilometers west of Goleta and just east of Carpinteria (figs. 2 and 3). The coastal plain surface includes numerous mesas and hills (fig. 3 ) that are geomorphic expressions of potentially active folds and partly buried oblique and reverse faults of the Santa Barbara fold and fault belt that transects the coastal plain (SBFFB, fig. 2) (Keller and Gurrola, 2000; Gurrola and others, 2001). [Note: Although Keller and Gurrola (2000) and Gurrola and others (2001) named the structural belt the "Santa Barbara Fold Belt", we refer to it as a "fold and fault belt" due to the common presence of both surficial folds and faults along it.] Strong earthquakes have occurred offshore within $10 \mathrm{~km}$ of the Santa Barbara coastal plain in 1925 (6.3 magnitude), 1941 (5.5 magnitude) and 1978 (5.1 magnitude). These and numerous smaller seismic events located beneath and offshore of the coastal plain, likely occurred on reverse-oblique-slip faults that are similar to, or continuous with, Quaternary reverse faults crossing the coastal plain (Yerkes and Lee, 1987). Thus, faults of the SBFFB pose a significant earthquake hazard to the approximately 200,000 people living within the major coastal population centers of Goleta, Santa Barbara, and Carpinteria. In addition, numerous Quaternary landslide deposits along the steep southern flank of the Santa Ynez Mountains (Bezore and Wills, 2000) indicate the potential for continued slope failures and mass movements in developed areas. Folded, faulted, and fractured sedimentary rocks in the subsurface of the coastal plain and adjacent Santa Barbara Channel are sources and reservoirs for economic deposits of oil and gas (Tennyson and Isaacs, 2001), some of which are currently being extracted offshore. Shallow, localized sedimentary aquifers underlying the coastal plain provide limited amounts of water for the urban areas, but the 
quality of some of this groundwater is compromised by coastal salt-water contamination (Upson, 1951; Muir, 1968).

\section{GEOLOGIC SUMMARY}

The western Transverse Ranges consist mainly of variably deformed marine and nonmarine sedimentary rocks and deposits that range in age from Jurassic to the present. These strata record a long history of continental-margin sedimentation, and deposits as young as middle Pleistocene record considerable protracted deformation that includes Neogene and Quaternary transpressional faulting, folding, and clockwise vertical-axis rotations of crustal blocks (e.g., Dibblee, 1966, 1982; Namson and Davis, 1988; Hornafius and others, 1986; Luyendyk, 1991; Dickinson, 1995; Gurrola and others, 2001). A dramatic result of this deformation is the prominent Santa Ynez Mountains directly north of the Santa Barbara coastal plain, which were uplifted along a large homoclinal to anticlinal structure beginning in the Pliocene (Dibblee, 1982).

In the map area the oldest stratigraphic units consist of Eocene resistant, southwarddipping, mostly marine sedimentary rocks along the south flank of the Santa Ynez Mountains uplift, which form a backdrop of prominent hogbacks and cuestas above Goleta Valley. Less resistant but similarly deformed, Oligocene through Pliocene terrestrial and marine sedimentary rocks are exposed in the lower Santa Ynez foothills on the north margin of the valley and in the coastal hills and sea cliffs to the south. Moderately faulted and folded or warped Pleistocene marine and terrestrial sediments underlie the hills and mesas on the north and southeast sides of Goleta Valley. Uplifted and locally warped upper Pleistocene marine-terrace deposits and underlying wave-cut platforms that underlie the coastal mesas are displaced by the large east-northeast-trending More Ranch fault system that spans the map area. Numerous large Quaternary landslide deposits are scattered throughout the precipitous southern flank of the Santa Ynez Mountains in the northern part of the quadrangle. Undisturbed Holocene alluvial and colluvial deposits directly underlie most of the low-lying parts of Goleta Valley and are locally present along stream canyons dissecting the lower flanks of the Santa Ynez Mountains.

\section{PREVIOUS MAPPING}

Willis (1925) produced the first fault map of the entire coastal plain area at a scale of $1: 62,500$ as part of an investigation of the large Santa Barbara earthquake of 1925. A second early fault map of the coastal plain within and adjacent to the Goleta $71 / 2$, quadrangle was produced by Hill (1932) at a scale of 1:125,000 in conjunction with a structural study of faulting in the area. The earliest systematic geologic mapping in the Goleta quadrangle was conducted in the early 1950's by Upson (1951), who mapped in reconnaissance the coastal plain region at a scale of 1:31,680 as part of a water resource study. Thomas W. Dibblee, Jr. (1966) produced the first comprehensive, detailed geologic maps of the Santa Barbara coastal plain region, which included coverage of the Goleta quadrangle at a scale of 1:62,500. As an aid to constructing subsurface geologic interpretations of the coastal plain region, Olson (1982) produced a 1:24,000-scale geologic map compilation of the Santa Barbara-Goleta area that was largely based on the previous 
mapping listed above. The Thomas Dibblee Foundation published separate geologic maps of the Carpinteria, Santa Barbara, Dos Pueblos, and Goleta $7 \frac{1}{2}$ ' quadrangles (Dibblee, 1986a, 1986b, 1987a, 1987b) at a scale of 1:24,000, which were largely based on geologic mapping compiled for the earlier Dibblee (1966) maps. The California Geological Survey (formerly California Division of Mines and Geology) produced 1:24,000-scale landslide inventory and landslide potential maps of the Santa Barbara coastal plain region (Bezore and Wills, 2000). A recent 1:24,000-scale, four-quadrangle geologic compilation of the Santa Barbara coastal plain (Minor and others, in press), which builds and expands upon an earlier preliminary map of the coastal plain in the Goleta and Santa Barbara quadrangles (fig. 2) (Minor and others, 2002), provides new geologic interpretations of the coastal region and provides much of the geologic map data used for compiling the present map. The new expanded compilation includes coverage of the coastal parts of the Dos Pueblos Canyon 7.5' quadrangle (west of Goleta quadrangle) and Carpinteria 7.5' quadrangle (east of Santa Barbara quadrangle) (fig. 2).

\section{PRESENT MAPPING}

The present geologic compilation of the Goleta quadrangle, along with the preliminary compilation that preceded it (Minor and others, 2002), comprise new, original mapping based on field and aerial-photo geologic observations and interpretations made on the ground surface or in shallow surface excavations, supplemented by new biostratigraphic identifications. In keeping with this surficial theme, and to owing to the questionable or conflicting stratigraphic picks in many of the petroleum industry drilling logs in the map area, no geologic cross sections are presented herein. The recently revised geologic time scale of the U.S. Geological Survey Geologic Names Committee (2007) was adopted for assigning geologic ages to map units in this report. In the description of map units, sedimentary lithologic terms and rock naming conventions are largely from Williams and others (1982).

Field-based geologic mapping and associated investigations in the Goleta quadrangle were conducted by three of the authors (Minor, Kellogg, and Stanley) in 2000 through 2002 and in 2005 and 2006. The initial field campaign (2000-2002), supported by the USGS Southern California Areal Mapping Project (SCAMP), contributed to a preliminary 1:24,000-scale geologic map of the central part of the coastal plain (Minor and others, 2002) within the coastal parts of the Goleta quadrangle and contiguous Santa Barbara quadrangle (fig. 2). Minor and Kellogg conducted all of the geologic mapping inland of the sea cliffs in the Goleta quadrangle during this early campaign, with Minor's efforts focused on the coastal piedmont and lower flanks of the Santa Ynez Mountains in the northeast part of the map area and Kellogg's mapping concentrated in the uplands of the northwest part of quadrangle. Minor also conducted most of the fault kinematic observations and measurements in the map area. Stanley chiefly mapped and documented stratigraphic details of the Miocene and Pliocene marine rocks exposed along the sea cliffs in the southern part of the quadrangle. The field mapping in 2005 and 2006 was conducted mainly by S.A. Minor, was supported chiefly by the USGS Basin and Landscape Co-Evolution (BALANCE) Project, and focused primarily on the 
mountainous northern quarter of the Goleta quadrangle. T.R. Brandt assisted in the design and editing of the GIS database and performed database integration.

Although our new mapping broadly resembles the earlier Dibblee (1966, 1987b) mapping in the area of the Goleta quadrangle, it differs significantly in the amount of stratigraphic and structural detail which results in new geologic interpretations and map depictions. In particular, new biostratigraphic and (or) lithologic criteria are established for differentiating the Sisquoc Formation and subunits of the Monterey and Sespe Formations, resulting in marked changes in the mapped positions of contacts for these units. The present compilation includes a more detailed description, differentiation, and mapping of upper Pliocene and Pleistocene marine and nonmarine units that bear on the Quaternary tectonic uplift and deformational history of the coastal plain region and the attendant interplay of marine and continental deposition. Structures are mapped in considerably greater detail than on the Dibblee maps, resulting in a more thorough and, in places, distinct documentation of faults and folds in Quaternary deposits underlying the Goleta coastal plain. Numerous fault attitude and kinematic data acquired during our mapping campaign provide new constraints on the geometry and movement history of both mapped and outcrop-scale faults.

As part of our geologic mapping efforts to document the structural geology of the coastal plain area, we collected kinematic data (slip-surface orientation and slickenline rake measurements and slip-sense determinations) from small- $(<5 \mathrm{~m})$ and larger-displacement $(5$ to $>100 \mathrm{~m}$ ) fault surfaces exposed in the map area within sedimentary rocks and deposits ranging in age from middle Eocene to late Pleistocene. Slip lineation (i.e., slickenline) bearing and rake measurements taken at exposures of larger-displacement faults are shown on the cartographic representation of the map, whereas all of the kinematic data (slip-lineation bearing, rake, slip sense, slip-sense certainty) from both larger-displacement faults and small-displacement minor faults are embedded as "point" data in the geologic map data base. Another structural detail of our mapping that deserves special note concerns distinguishing youthful folds formed in Pleistocene deposits from folds formed in older rocks: Anticlines and synclines, which are geomorphically and structurally well expressed in Pleistocene alluvial deposits but which commonly have poor structural definition in underlying, discordant bedrock units, are mapped as upwarps and downwarps, respectively. 


\section{DESCRIPTION OF MAP UNITS}

af

Qa

$\mathrm{Qb}$

Qe

Qas

Asphalt deposits (Holocene) - Black, tar-like asphalt that represent weathered and biodegraded oil derived from nearby natural seeps. Moderately hard to very hard and brittle; freshly broken pieces emit a strong petroliferous odor. Primarily form low mounds $1-10 \mathrm{~m}$ across and 1-3 m thick and drape-like accumulations on the sea cliff 1-5 $\mathrm{m}$ across and 1-5 $\mathrm{m}$ high; such deposits are depicted on map by point symbols. Also form sheets of undetermined thickness that extend laterally for tens of meters. Locally contain shells, angular fragments of older asphalt, and rock fragments. Commonly overlie beach sand and older landslide deposits derived from erosion of the modern sea cliff; commonly overlain by recent beach sand and landslide deposits. Exposed surfaces of some accumulations are overgrown by intertidal organisms and terrestrial vegetation. Typically spatially associated with asphalt-filled fractures in Pleistocene sandstone unit (Qss) and Pleistocene and Pliocene siltstone unit (QTst)

Qdf Debris-flow deposits (Holocene and upper Pleistocene?)-Massive, weakly consolidated, coarse-grained, poorly sorted, generally matrix-supported 
rock-debris breccia. Mainly located along lower flanks of Santa Ynez Mountains in northern map area and composed of sandstone and mudstone debris derived from Coldwater Sandstone (Tcw) and Sespe Formation (Tspu, Tspm, Tspl) exposed upslope.

Youthful, lobate geomorphic expression of most deposits suggests that they are Holocene in age, but considerable erosional dissection of some suggest some debris flows were emplaced during the late Pleistocene. Most deposits estimated to be less than $5 \mathrm{~m}$ thick

Qac Alluvium and colluvium (Holocene and upper Pleistocene)-Unconsolidated to weakly consolidated silt, sand, and gravel deposits of modern drainages, alluvial fans, and floodplains. Deposits inferred to underlie much of the urbanized Goleta Valley and many of the larger broad canyon floors to the north of it. Where exposed, alluvium is composed of poorly to moderately sorted silt, sand, and pebble to boulder gravel that commonly occupy paleochannels. Flanking colluvial deposits are composed primarily of poorly sorted, angular clasts, with longest axis as great as $1 \mathrm{~m}$, in a finegrained matrix. Geomorphic surfaces underlain by alluvium and colluvium commonly contain poorly to moderately developed soil profiles and exhibit weak to moderate erosional dissection. Exposed thickness of alluvial and colluvial deposits generally less than $10 \mathrm{~m}$

Qc Colluvium (Holocene and upper Pleistocene)-Unconsolidated to weakly indurated, mostly non-stratified, dark-brown to light-gray-brown deposits that mantle gentle to moderate slopes. Consists of angular to subrounded pebbles, cobbles, and boulders mixed with fine-grained material, mostly derived from weathering and down-slope movement of nearby bedrock. Includes sheetwash deposits and some small landslide deposits on slopes, minor alluvium in small channels, and deposits of wind-blown sand, silt, and minor clay in areas of open gentle slopes. Colluvial deposits commonly capped by poorly to moderately developed soil profiles. Smaller colluvial deposits are not mapped, particularly where thin and discontinuous. Maximum thickness of colluvial deposits probably less than $15 \mathrm{~m}$

Q1s Landslide deposits (Holocene to middle Pleistocene) -Deposits of diverse slope-movement processes including earth slides, earth flows, rock slides, debris slides and rock slumps (Bezore and Wills, 2000; terminology of Cruden and Varnes, 1996). Deposits range from poorly sorted, disrupted mixtures of rock fragments and soil to relatively intact bedrock slump blocks. Surfaces of deposits commonly hummocky; relatively steep breakaway zones identifiable in places. Rincon Shale (Tr), middle shale unit of Monterey Formation (Tmm), and relatively fine grained intervals in the Sespe Formation (Tspu, Tspm, Tspl) and Coldwater Sandstone (Tcw) are particularly susceptible to sliding (mostly by earth flow), although slides have occurred in most units where oversteepening of slopes has promoted slip. Largest landslide deposits may be as thick as $60 \mathrm{~m}$ 
Qtc Travertine and caliche? deposits (Holocene? and Pleistocene?)-White, massive, low-density, locally vuggy deposits of very fine-grained, micritic calcium carbonate. Contains embedded pebbles as long as about $5 \mathrm{~cm}$. Small deposits are located at two sites in central part of map area and are depicted by point symbols. At one locality just north of Cathedral Oaks Road, $0.5 \mathrm{~km}$ northeast of intersection with Los Carneros Road, carbonate forms layers as thick as about $10 \mathrm{~cm}$ within soil that also comprises numerous float blocks scattered on hillside. This deposit may be either travertine precipitated from an ancient fault-related(?) carbonate-rich spring or pedogenic caliche. Just west of Fairview Avenue, $0.5 \mathrm{~km}$ north of Cathedral Oaks Road, travertine forms globular masses as thick as $0.5 \mathrm{~m}$ that probably resulted from now-inactive spring activity

Qia Intermediate alluvial deposits (upper Pleistocene)-Orange-brown to tan, weakly consolidated, stratified silt, sand, and pebble, cobble, and rare boulder gravel. Well-rounded clasts, rarely longer than $10 \mathrm{~cm}$, include Eocene marine sandstone, sandstone from the Sespe Formation, and rare reworked, rounded cobbles and pebbles derived from conglomerates of the Sespe Formation. Forms low, rounded, moderately dissected terraces that are as high as about $15 \mathrm{~m}$ above the modern coastal piedmont surface. Average clast size decreases to south, away from sources in the Santa Ynez Mountains.

North and west of Goleta, where northern edge of unit approximately coincides with a possible older, elevated shore line angle (that is, the landward edge of a marine abrasion platform), the unit may include older marine-terrace deposits (Qmt). Just west of map area, intermediate alluvial deposits grade laterally into a coastal strip of marine terraces (Minor and others, in press). Intermediate alluvial deposits are topographically lower and, thus, younger than adjacent older alluvial deposits (Qoa), and generally contain smaller clasts. However, in some areas, deposits mapped as intermediate in age may be temporally equivalent to deposits mapped as older alluvial deposits (Qoa) in other areas.

Late Pleistocene age of unit mainly based on lateral correlation with relatively well-dated marine terrace deposits (Qmt) and late Pleistocene age of underlying older alluvial deposits (Qoa).

Unit was previously mapped as fanglomerate, older alluvium, and alluvium (Dibblee, 1966) and older dissected surficial sediments (Dibblee, 1987b). Base of unit not exposed; thickness probably locally greater than $20 \mathrm{~m}$

Qmt Marine terrace deposits (upper Pleistocene)-Mostly pale- to medium-tan, brown, and -gray, weakly to moderately consolidated, crudely to moderately bedded, pebble-cobble gravel and conglomerate, pebbly to conglomeratic sand and sandstone, and silt and siltstone. Deposits unconformably overlie 
eroded bedrock or older sediments on elevated marine wave-cut abrasion platforms. Lower part of marine-terrace sequences typically consists of a thin ( $\leq 1 \mathrm{~m}$-thick) basal layer of fossiliferous cobble to pebble gravel or conglomerate that locally grades upward into laminated to massive beach(?) sand or sandstone and (or) estuarine organic-rich clay and silt. Basal gravel and conglomerate clasts commonly exhibit mollusk (pholad) borings that rarely contain pholad shells. An open-coast invertebrate fauna of at least 125 taxa, including 102 mollusks and 18 foraminifers, has been collected from the lowermost emergent terrace of this unit near Goleta (Wright, 1972; C.L. Powell II, U.S. Geological Survey, unpub. data, 2001). The mollusks from this terrace inhabited an exposed rocky and sandy shore from intertidal to inner sublittoral depths (0-9 m) (Valentine, 1961; Wright, 1972). Among the fauna is the rare fossil solitary coral Balanophyllia elegans (Verrill) (Gurrola and others, 2001). Upper two-thirds or more of terrace sequences typically includes nonmarine eolian sand or sandstone and silt or siltstone, stratified fluvial and alluvial pebble-cobble gravel or conglomerate, and minor colluvial deposits.

Marine-terrace deposits are well exposed in upper parts of the sea cliffs that span east-west nearly continuously across the map area. Marine-terrace deposits probably underlie the elevated, locally dissected coastal mesas that extend inland from the sea cliffs and, in western Goleta Valley, may extend beneath the broad area of moderately dissected intermediate alluvial deposits (Qia). Positive correlation of small, poorly exposed deposit north of Lake Los Carneros (labeled Qmt?) with marine-terrace unit awaits age determination of marine fossils that are contained within it. Flights of marine terraces and underlying marine-terrace deposits are locally preserved along the coast and are bounded along their back edges by shoreline angles that mark bases of adjacent terrace-riser scarps (erosionally modified paleosea cliffs?). In the Hope Ranch area on either side of southern Las Palmas Drive, as many as four terrace surfaces, formed on four distinct levels of marine-terrace deposits, are preserved ranging in elevation from about $30 \mathrm{~m}$ to as high as $90 \mathrm{~m}(100-300 \mathrm{ft})$ above modern sea level. Elevation of lowest emergent marine terrace in Isla Vista area is about $10 \mathrm{~m}(30-40 \mathrm{ft})$.

Marine-terrace basal-abrasion surfaces in map area probably formed during interglacial sea-level high stands, whereas the overlying terrace deposits most likely accumulated during marine regressions resulting from eustatic drops in sea level and (or) tectonic uplift (Rockwell and others, 1992; Muhs and others, 1992; Keller and Gurrola, 2000; Gurrola and others, 2001). First emergent marine terraces in Isla Vista (10 $\mathrm{m}[30-40 \mathrm{ft}]$ approximate elevation) and More Mesa (30 $\mathrm{m}[60-100 \mathrm{ft}])$ areas are dated at approximately $45 \mathrm{ka}$ and are correlated to oxygen isotope substage $3 \mathrm{a}$ sealevel high stand, based on integrated results from uranium-series analysis of marine terrace corals, ${ }^{14} \mathrm{C}$ ages of terrace shells and detrital charcoal, optically stimulated luminescence (OSL) of terrace sands, and oxygen isotopic signatures of terrace mollusks (Keller and Gurrola, 2000; Gurrola and others, 2001). Flights of higher marine terraces preserved in the Hope 
Ranch (30-90 m [100-300 ft] elevation range) area range in age from $70 \mathrm{ka}$ to $105 \mathrm{ka}$ and correlate to oxygen isotope substages 5a and 5c sea-level high stands (Gurrola and others, 2001). Keller and Gurrola (2000) infer that marine terraces forming the narrow, dissected coastal bench west of the map area (20-45 $\mathrm{m}$ [70-140 ft] elevation range) also correlate with oxygen isotope stage 5, and they infer that these older terraces extend eastward into northwest Goleta Valley in areas mapped herein as intermediate alluvial deposits (Qia). Dibblee (1966) reported the presence of a jaw bone of a late Pleistocene mammoth (Archidiscodon imperator) in alluvium within laterally equivalent marine terrace deposits about $12 \mathrm{~km}$ west of the map area.

Alluvial deposits typically present in upper part of marine terrace sequences probably correlate with intermediate (Qia) and older (Qoa) alluvial deposits. Marine terrace deposits of this report were previously mapped as terrace deposits (Upson, 1951), older alluvium (Dibblee, 1966), and older dissected surficial sediments (Dibblee, 1987b). Maximum exposed thickness about $20 \mathrm{~m}$

Qoa Older alluvial deposits (upper and middle Pleistocene) - Nonmarine brown, pale-gray, pale-tan, and reddish-brown, moderately consolidated, crudely stratified, poorly sorted, clayey to silty and pebbly sand and sandstone, silty to sandy pebble-cobble-boulder gravel, conglomerate, and breccia, and rare interbeds and partings of sandy to pebbly clay, silt, and mudstone. Sand and sandstone are locally cross laminated. Gravel and conglomerate typically occupy paleochannels or form lenticular beds, and contain subrounded clasts composed primarily of sandstone derived from Eocene formations exposed in Santa Ynez Mountains. Clasts commonly are imbricated. Breccia composed of subangular clasts mainly of Eocene sandstone typically forms thick ( $>3 \mathrm{~m}$ ), sheet-like, clast-supported beds probably deposited as debris flows. Most older alluvial deposits are poorly to moderately consolidated, but locally are indurated where cemented.

Along front of Santa Ynez Mountains, unit typically forms dissected, gently south sloping terraces and interfluvial caps, as much as $100 \mathrm{~m}$ above modern stream level, interpreted as erosional remnants of old alluvial fans. Clast size generally decreases and sorting increases away from mountain front; coarse breccia deposits, restricted to northern, proximal parts of fan remnants along mountain flanks, include blocks several meters in length. Finer-grained, medial and distal facies commonly erode into badlands topography. On coastal plain unit is deformed and uplifted by youthful upwarps, folds, and faults and forms rounded hills and ridges, including the lower hills in northern Goleta Valley. Some low-lying areas of urban development are inferred to be underlain by older alluvial deposits on the basis of geomorphology; such areas are slightly higher in elevation and exhibit greater erosional dissection than adjacent areas of presumably younger deposits (Qac, Qia) and were mapped primarily by means of air photographs and digital elevation models. Existence of older alluvial 
deposits on small ridge crests southwest of Laguna Blanca (areas labeled Qoa?) is uncertain due to lack of exposures.

In most places, the unit overlies Tertiary bedrock units with marked angular discordance. At several localities near El Sueno and in east-central part of map area, older-most alluvial deposits of unit are interstratified with and conformably overlie sandstone of upper Santa Barbara Formation (Qsb). These deposits closely resemble, and may be correlative with, sediments of the Casitas Formation, which was first defined and mapped by Upson (1951) in the Rincon Creek area $30 \mathrm{~km}$ east of map area. More commonly, however, older alluvial deposits unconformably overlie rocks of the Santa Barbara Formation with as much as $30^{\circ}$ of angular discordance. Most older alluvial deposits of this report were previously mapped as older alluvium (Upson, 1951), fanglomerate (Dibblee, 1966), and older dissected surficial sediments (Dibblee, 1987b). Coarser-grained intervals within the older alluvial deposits yield significant quantities of groundwater in wells and the unit forms one of the principal aquifer units beneath Goleta Valley (Upson, 1951; Muir, 1968).

Unit age is constrained by middle and lower Pleistocene Santa Barbara Formation (Qsb) that underlies and locally interfingers with lower older alluvial deposits, and by elevated, upper Pleistocene marine-terrace deposits (Qmt) into which distal facies of older alluvial deposits appear to grade. Maximum exposed thickness is approximately $35 \mathrm{~m}$, but thickness probably is much greater in subsurface under coastal plain

Qsb Santa Barbara Formation (middle and lower Pleistocene)-Marine, mostly pale-gray and cream-colored (fresh) to buff, pale-tan, and pale-yellow (weathered), friable, fine- to medium-grained sandstone and pebbly sandstone. Sandstone ranges from bioturbated and massive to crudely or moderately tabular-bedded and planar- to cross-laminated. Locally, palegray sandstone is weakly to strongly cemented with carbonate and forms "curb-and-gutter" concretions subparallel to bedding. Pebble- and rare cobble-bearing conglomeratic sandstone lenses and intervals contain generally well rounded polymict clasts that include siliceous shale possibly derived from Monterey Formation ( $\mathrm{Tmu}, \mathrm{Tmm}$ ), sandstone possibly derived from Eocene formations exposed in Santa Ynez Mountains (including Tspl, Tcw), and intermediate-to-silicic volcanic rocks possibly reworked from conglomerates of the Sespe Formation (Tspm, Tspl). Conglomeratic layers become more common up-section in exposures near El Sueno and south of La Cumbre Junior High School and Harding School in central part of map area. Partings, interbeds, and thin-bedded intervals of gray and palegreenish-gray, laminated shale, siltstone, and silty to clayey fine-grained sandstone are subordinate; these commonly contain layers rich in shell hash and locally are stained with rusty-orange iron oxide. Diverse marine invertebrate assemblages of mollusks, bryozoans, and foraminifers are concentrated in multiple stratigraphic intervals, ranging in thickness from less than $1 \mathrm{~m}$ to several tens of meters, distributed throughout all but the 
uppermost, conglomeratic parts of unit. Typically, shells are disarticulated, fragmented, and concentrated in planar beds and lenses in both sandstone and finer grained intervals. Unit includes sparse, whitish beds of calcareous coquina, 0.5 to about $3 \mathrm{~m}$ thick and composed almost entirely of shell and (or) bryozoan fragments, and thin layers rich in carbonaceous (fossil plant?) fragments.

Unit typically is poorly exposed and forms subdued rounded hills except in a few locations where it is strongly cemented and forms resistant outcrops and cliffs; silt- and clay-rich intervals locally erode into badlands topography. Maximum exposed thickness is approximately $300 \mathrm{~m}$. Type section of formation is near Santa Barbara City College about $3 \mathrm{~km}$ east of map area (Dibblee, 1966, 1986b). This section, which exposes a fossiliferous stratigraphic interval about $40 \mathrm{~m}$ thick, is fairly representative of finer-grained, thinly bedded intervals of Santa Barbara Formation, but not of the friable, massive to crudely stratified sandstone that characterizes most of unit in map area.

A slight to moderate angular unconformity separates Santa Barbara Formation from underlying Miocene and older units (Tv, Tr, and Tml) along the northern edge of a west-northwest-trending belt of discontinuous exposures extending from Laguna Blanca to the foothills northwest of Goleta. Surface trace of this unconformity marks northern limit of exposures of unit in central map area, but presence of shelf molluscan fossils and lack of shoreface fossils in northern exposures of formation (C.L. Powell II, written commun., 2001) suggests that original depositional basin extended an unknown distance farther north (cf., Dibblee, 1966). Upper contact of Santa Barbara Formation with younger sedimentary units is generally unconformable and discordant, but Santa Barbara is locally gradational or interstratified with lower conglomerates and gravels of the older alluvial deposits unit (Qoa).

Molluscan fossils from Santa Barbara Formation examined by C.L. Powell II (written commun., 2001) characteristically include bivalves Chlamys spp., Cyclocardia occidentalis (Conrad), C. californica (Dall), Humilaria perlaminosa (Conrad), Lucinoma annulatum (Reeve), Patinopecten caurinus (Gould), Pecten bellus (Conrad), and gastropods Amphissa reticulata (Dall), Boreotrophon spp., Crepidula princeps (Conrad), Olivella biplicata (Sowerby), Neptunea tabulata (Baird), and Turritella cooperi Carpenter. The molluscan fauna are consistent with deposition at shelf water depths and a possible late Pliocene to middle Pleistocene age (C.L. Powell II, written commun., 2001). In addition, a few mollusks known to be no younger than Pliocene, including bivalves Dendostrea? vespertina (Conrad) and Patinopecten healeyi (Arnold) and gastropod Nassarius grammatus (Dall), have been reported from the Santa Barbara Formation (Addicott, 1965; Los Angeles County Museum of Natural History collections), but these findings have not been independently confirmed. Previously, Dibblee (1966) presented a list of molluscan fossils 
from formation interpreted to indicate a "late Pliocene(?) to early Pleistocene" age.

Middle and early Pleistocene age provisionally assigned to Santa Barbara Formation in this report is based partly on reconnaissance paleomagnetic data from the coastal plain area. These data suggest that much of the formation was deposited during normal polarity epoch following the Brunhes-Matuyama geomagnetic reversal at about $780 \mathrm{ka}$ (Keller and Gurrola, 2000; Gurrola and others, 2001; J.W. Hillhouse, U.S. Geological Survey, written commun., 2007). However, in at least one exposure in northwestern Goleta Valley (north of Lake Los Carneros) fossilbarren, possible Santa Barbara sandstone (mapped as Qsb?) has reverse polarity suggesting that it was deposited during the preceding Matuyama (2.60-0.78 Ma) interval (J.W. Hillhouse, written commun., 2007). Middle and early Pleistocene age also is consistent with (1) a reported amino-acid racemization age of 500-600 ka for formation near old Santa Barbara Hospital site (Wehmiller, 1992), (2) strontium isotope data suggesting an age of 400-900 ka for formation near Santa Barbara Harbor $4 \mathrm{~km}$ east of map area (Patterson and others, 1990), (3) a shift from predominantly dextral to sinistral coiling in planktic foraminifer Neogloboquadrina pachyderma, indicating an age of about $600 \mathrm{ka}$, within formation near Santa Barbara Harbor (Patterson and others, 1990), and (4) a 1.2-Ma age determination for the Bailey ash (Izett, Naeser, and Obradovich, 1974), which directly underlies the Santa Barbara Formation in the Ventura area about $45 \mathrm{~km}$ east of map area (Yerkes, Sarna-Wojcicki, and Lajoie, 1987).

Unit was previously mapped as Santa Barbara Formation by Upson (1951) and Dibblee (1966, 1987b). Coarser-grained intervals within the unit yield significant quantities of groundwater in wells and the Santa Barbara Formation forms one of the principal aquifer units beneath Goleta Valley (Upson, 1951; Muir, 1968)

\section{Unnamed sedimentary rocks east of Goleta Pier (Pleistocene and}

Pliocene?) - Marine conglomerate, sandstone, siltstone, and mudstone exposed along coast 1.5 to $3.5 \mathrm{~km}$ east of Goleta Pier (south-central part of map area), previously mapped as unnamed upper Pliocene formation (Upson, 1951), Pico Formation (Dibblee, 1966), and Santa Barbara Formation (Dibblee, 1987b). In this study, mapped as three unnamed, lithologically distinct units:

Qcg Conglomeratic unit (middle and lower Pleistocene)-Conglomerate, sandstone, siltstone, and mudstone probably deposited within ancient submarine canyon. Conglomerate is mostly clast supported and consists of angular to rounded granules, pebbles, cobbles, and boulders in a poorly sorted, friable to hard (calcareous), sandy and silty matrix. Clasts larger than $20 \mathrm{~cm}$ commonly are oriented parallel to bedding. Conglomerate beds typically are lenticular and range in thickness from a few centimeters to about $5 \mathrm{~m}$. Some conglomerate beds exhibit inverse-to-normal grading; 
others exhibit complex, lenticular internal stratification marked by variations in clast size. Bases of most conglomerate beds are sharp, irregular, and erosional. Weak clast imbrication in two beds suggests paleoflow generally to west, southwest, and south. Clasts in lower parts of unit are mainly mudstone, shale, porcelanite, dolomite, and subordinate black phosphorite inferred to be derived from Sisquoc and Monterey Formations; clasts higher in unit additionally include abundant fine- to coarse-grained sandstone possibly derived from Paleogene and Mesozoic strata in the Santa Ynez Mountains. Benthic foraminifers and calcareous nannofossils from one dark-brown mudstone clast indicate derivation from middle or lower parts of the Monterey Formation (Tmm or Tml) (R.S. Boettcher and S.A. Kling, Micropaleo Consultants, written commun., 2001). Largest clasts are angular to subrounded boulders of dolomite as much as $1.2 \mathrm{~m}$ long; most clasts larger than $10 \mathrm{~cm}$ are mudstone, shale, and dolomite. Clasts also include minor gray chert, red quartzite, and gabbro or diorite derived from unknown sources; black, glassy chert possibly derived from the Monterey Formation; and angular, irregularly-shaped clasts of bioturbated fine-grained sandstone and siltstone possibly derived from the associated sandstone and (or) siltstone units (Qss, QTst).

Unit also includes (1) bioturbated siltstone and sandstone; (2) laminated, fine- to coarse-grained sandstone; and (3) thin-bedded sandstone and mudstone. Bioturbated siltstone and poorly sorted, very fine to fine-grained sandstone are friable to moderately hard, brown to gray and blue-gray on freshly broken surfaces, weather gray to tan with some orange and yellow mottling, and occur in beds ranging in thickness from a few centimeters to more than $2 \mathrm{~m}$. Some beds contain scattered granules, pebbles, and cobbles, thin lenses of conglomerate, and molluscan shells and shell fragments. Fractures commonly are partly filled by jarosite. Bioturbation is defined by textural and color mottling and by knobby, irregular weathering surfaces.

Laminated, fine- to coarse-grained sandstone is gray on fresh surfaces, weathers light brown to tan, is poorly to well sorted, and ranges from friable to hard. Hard sandstone is variably calcareous and forms prominent ledges. Sandstone forms lenses within conglomerate and laterally persistent beds less than $50 \mathrm{~cm}$ to $5 \mathrm{~m}$ thick. Most beds are amalgamated; some marked by thin gray-brown clay-rich horizons up to $3 \mathrm{~cm}$ thick. Some beds exhibit normal grading from pebbly and granular sandstone at base to fine sandstone at top. Sedimentary structures include plane lamination, ripple cross lamination, convolute lamination, and low-angle scour and fill; basal bed surfaces commonly are erosional. Granules, pebbles, and cobbles of mudstone and dolomite apparently derived from Sisquoc and (or) Monterey Formations are common as scattered clasts and in lenses of conglomerate.

Intervals of thin-bedded sandstone and mudstone are poorly exposed and generally $1-5 \mathrm{~m}$ thick. Sandstone is friable, very fine to fine-grained, generally well sorted, and weathers white to light brown. Sandstone beds are 5-20 $\mathrm{cm}$ thick and interstratified with beds of mudstone $1-3 \mathrm{~cm}$ thick. Many sandstone beds exhibit irregular, gradational, and apparently 
bioturbated contacts with underlying and overlying mudstone beds; some have abrupt erosional lower contacts. Sedimentary structures include plane lamination, ripple cross lamination, and convolute lamination. Some sandstone beds exhibit partial Bouma sequences that may represent turbidites. Local observations on ripple cross laminations suggest paleoflow generally to the west and southwest. Mudstone is gray to brown, clayey and silty, bioturbated, and generally harder and more consolidated than interlayered sandstone.

Unit is inferred to have been deposited in a submarine canyon or channel eroded into underlying units. Width of channel as exposed in sea cliff is about $610 \mathrm{~m}$. Eastern contact of unit with Sisquoc Formation (Tsq) is a west-dipping buttress unconformity; western contact with underlying sandstone unit (Qss) is an east-dipping buttress unconformity. Both contacts are abrupt, irregular, and clearly erosional. Unit is unconformably overlain by marine-terrace deposits. Base of unit in thickest, axial part of channel is not exposed; minimum thickness of unit in this area is $33 \mathrm{~m}$. Preliminary evidence suggests that much of the conglomerate was deposited by submarine debris flows and/or high-density turbidity currents, whereas much of the sandstone and siltstone may have been deposited by lowdensity turbidity currents.

Locally abundant marine fossils in conglomerate and sandstone intervals consist mainly of mollusks and arthropods. Mollusks identified by W.P. Woodring and reported by Upson (1951) and Dibblee (1966) were interpreted as being late Pliocene(?) to early Pleistocene, but reinterpretation of these identifications, supplemented with museum and recent collections, by C.L. Powell II (written commun., 2001) have found no Pliocene indicators. A single shark tooth (Carcharinus) was identified by J.D. Stewart (Los Angeles County Museum of Natural History). The fauna are distinguishable from the Santa Barbara Formation fauna only by the presence of shallow water, open-coast taxa and coarser sediments, and the two units are probably of similar age

Sandstone unit (lower Pleistocene?)—Laminated and bioturbated feldspathic sandstone, siltstone, and subordinate mudstone and conglomerate. Lower part of unit consists mainly of couplets of laminated sandstone and bioturbated sandstone and siltstone 30-100 cm thick. Laminated sandstone is gray, weathers light gray to light brown, and ranges from fine to coarse grained and moderately to well sorted; some beds contain scattered granules, pebbles, and cobbles of mudstone, shale, and dolomite derived from the Sisquoc and (or) Monterey Formations, in addition to scattered, poorly preserved molluscan shells and shell fragments. Planar to gently undulatory laminations mostly $0.5-1 \mathrm{~cm}$ thick are defined by variations in grain size and color banding and in places resemble hummocky cross-stratification. Convolute laminations are present locally. Lower contacts of laminated sandstone beds are abrupt and in places clearly scoured into the underlying bioturbated beds with up to $5 \mathrm{~cm}$ erosional 
relief. Bioturbated sandstone and siltstone are fine to medium grained, moderately to poorly sorted, gray to brown on freshly broken surfaces, weather light brown, and are generally softer and less resistant than the laminated sandstone. Bioturbation is defined by textural and color mottling; individual burrows are well preserved in some beds and exhibit vertical, horizontal, and oblique orientations. Where weathered, both laminated and bioturbated beds are soft and friable and contain abundant jarosite along fractures.

Poorly exposed intervals of white- to tan- weathering and friable to wellconsolidated sandstone overlie laminated sandstone beds. Beds are 5-100 $\mathrm{cm}$ thick but generally less than $50 \mathrm{~cm}$ thick; most are lenticular. Some beds appear to be massive but others exhibit planar and (or) convolute lamination.

Conglomerate constitutes 1-2 percent of unit and occurs mainly as lenses $10-50 \mathrm{~cm}$ thick and less than $5 \mathrm{~m}$ in lateral extent. Most clasts are angular to subrounded granules and pebbles less than $5 \mathrm{~cm}$ long, although some are as long as $30-50 \mathrm{~cm}$. Most clasts are laminated shale, mudstone, porcelanite, and dolomite derived from the Sisquoc and (or) Monterey Formations. Benthic foraminifers from one mudstone clast indicate derivation from lower part of the Monterey Formation (Tml) (R.S. Boettcher and S.A. Kling, written commun., 2001).

Contact with siltstone unit (QTst) is covered by vegetation and soil but is inferred to be a fault; depositional base of unit is not exposed, and stratigraphic relation with siltstone unit is uncertain. Exposed thickness of sandstone unit is 45-60 m. Preliminary work suggests that unit may have been deposited below fair-weather wave base on a storm-dominated marine shelf, perhaps at water depths of 10-100 m.

Age of sandstone unit is uncertain owing to lack of age-diagnostic fossils. Questionable early Pleistocene age is based on general lithologic resemblance of conglomerate, sandstone, and siltstone in unit to strata of better-dated siltstone and conglomeratic units (QTst, Qcg)

Siltstone unit (lower Pleistocene and upper Pliocene?)—Siltstone, mudstone, and silty, very fine to fine-grained sandstone; moderately hard, dark gray-brown to brown on freshly broken surfaces, weathering light brown to gray, massive and extensively bioturbated. Stratification is generally indistinct and, where visible, poorly defined by subtle variations in color, resistance to weathering, and types and relative abundance of trace fossils; individual beds generally range from about $10 \mathrm{~cm}$ to $1 \mathrm{~m}$ or more in thickness. In places, siltstone and sandstone contain abundant mica and (or) fragments of land plants. Pebbles and granules of rock fragments are uncommon and include dolomite derived from the Sisquoc and (or) Monterey Formations and porphyritic dacitic rock of unknown derivation. Scattered, poorly preserved mollusk shells and shell fragments suggest shelf deposition, or possibly deeper. The bivalve mollusk Cylocardia sp., and gastropods Amphissa reticulata Dall, Antiplanes sp., and Exilioidea sp. are 
present in unit, but they are not age diagnostic (C.L. Powell II, written commun., 2001). Modern representatives of these taxa coexist in the coastal waters of Southern California at depths between about 60 and $200 \mathrm{~m}$. Microfossils are abundant in the unit and include benthic foraminifers, ostracodes, and sponge spicules. Jarosite and gypsum are locally abundant along fractures. Locally, unit is cut by asphalt-filled fractures, some of which may represent exhumed conduits or "feeder dikes" in which oil migrating from source rocks at depth reached the surface and created accumulations of asphalt (Qas).

Contact with Sisquoc Formation (Tsq) is covered by landslide deposits and asphalt (Qas) and may be a fault. Depositional base of siltstone unit is not exposed, but general discordance between gently dipping beds of unit and more steeply dipping beds of older Sisquoc Formation suggests an unconformable relation. Unit is unconformably overlain by marine terrace deposits (Qmt). Exposed thickness is about $45 \mathrm{~m}$.

Contains benthic foraminiferal assemblages indicative of Wheelerian Stage (of Natland, 1952, and Kleinpell, 1980) and upper to middle bathyal (150-2000 m) water depths (R.S. Boettcher, written commun., 2001).

Wheelerian Stage is considered very latest Pliocene and early Pleistocene in age (McDougall and Lagoe, 1993, p. 7; K.A. McDougall, U.S. Geological Survey, written commun., 2001).

Seacliffs formed by unit about $2.1 \mathrm{~km}$ east of Goleta Pier are actively eroding; some man-made structures along the tops of the cliffs have been undermined by erosion. In places, outcrops of unit are partly covered by sea walls and retaining walls.

Poorly exposed strata along the western More Ranch fault system on Mescalitan Island (near Santa Barbara Airport) and in the cliffs southwest of Goleta Slough are assigned to siltstone unit because they are lithologically similar to exposures east of Goleta Pier, and because samples yielded benthic foraminiferal assemblages indicative of Wheelerian Stage and upper bathyal to upper middle bathyal (150-1500 m) water depths (R.S. Boettcher, written commun., 2001; 2002). Fine-grained sedimentary rocks on the north side of More Mesa just south of Atascadero Creek (mapped as QTst?) questionably assigned to the siltstone unit owing to very poor exposures and lack of biostratigraphic ages

Tsq Sisquoc Formation (lower Pliocene and upper Miocene)-Marine diatomaceous mudstone and shale, conglomerate, and subordinate dolomite. Distinguished from the underlying upper siliceous unit of the Monterey Formation (Tmu) by the occurrence of prominent, thick beds of conglomerate composed of angular clasts derived from the Monterey, and by contrasting assemblages of fossil diatoms.

Diatomaceous mudstone and shale are tan to white weathering, gray to brown on freshly broken surfaces, and contain zones of fractures lined with common to abundant jarosite and gypsum. Mudstone is generally soft to moderately hard; shale ranges from soft to hard and brittle. Both 
mudstone and shale are generally of conspicuously low density. Reaction in dilute hydrochloric acid $(\mathrm{HCl})$ ranges from weak to strong, indicating the presence of variable amounts of carbonate minerals. Foraminifers, diatoms and diatom debris (in some cases with opaline luster), fish fragments, radiolarians, sponge spicules, and molluscan shells and shell fragments are common to abundant, particularly along surfaces that are broken parallel to stratification. Most mudstone and shale beds are moderately to strongly laminated but some are massive and bioturbated. Laminations, generally $0.5-10.0 \mathrm{~mm}$ thick, are defined by light and dark color bands and variations in the types and abundance of microfossils and microfossil debris. Some cream-colored laminae may be phosphatic. Laminations within some beds are deformed into soft-sediment folds with amplitudes and wavelengths of a few centimeters to a few tens of centimeters. In places, such as the Goleta Point area, strongly fractured mudstone exhibits hydrocarbon staining and a petroliferous odor. At Coal Oil Point just west of map area, mudstone and shale within the stratigraphically lowest $80-100 \mathrm{~m}$ of the Sisquoc Formation are hard, brittle, and porcelaneous.

Dolomite constitutes less than one percent of the formation and forms laterally persistent beds generally less than $30 \mathrm{~cm}$ thick, ranging to $100 \mathrm{~cm}$ thick, and ellipsoidal to spheroidal concretions as much as about $100 \mathrm{~cm}$ in longest dimension. Dolomite is very hard, gray on freshly broken surfaces, weathers white to light orange or light brown, and is aphanitic to sugary in texture. Some is strongly calcareous. Laminations, mostly 1-10 $\mathrm{mm}$ thick but as much as $20 \mathrm{~mm}$ thick, are defined by alternating light and dark color banding and by subtle variations in texture. Some distinctive cream-colored laminations may be phosphatic. In some beds, the laminations are involved in small-scale, disharmonic folds with wavelengths and amplitudes of a few centimeters to tens of centimeters that are interpreted to reflect soft-sediment deformation. Fish fragments and poorly preserved microfossils, including foraminifers, are common.

Conglomerate consists mainly of angular to subrounded clasts of mudstone, shale, dolomite, porcelanite, and phosphorite apparently derived from the underlying Monterey Formation. Clasts range from granules to boulders; most are smaller than $30 \mathrm{~cm}$ but blocks up to $1 \mathrm{~m}$ across are common and the largest blocks are more than $10 \mathrm{~m}$ across. In most outcrops, the largest blocks are composed of hard, laminated dolomite or porcelanite, whereas shale and mudstone blocks are generally smaller. Most conglomerate beds are about $10 \mathrm{~cm}$ to $5 \mathrm{~m}$ thick and some may be as thick as 10-20 m. Laminated clasts typically are oriented at various angles to each other and bedding. However, some large, elongate clasts are parallel or subparallel to stratification. In many places the clasts are tightly packed; the matrix between the clasts, where present, is massive, diatomaceous mudstone. Conglomerate beds are easily recognized in fresh exposures along sea cliffs but are difficult to recognize in weathered or strongly fractured exposures. Conglomerate is well 
exposed in sea cliffs about 3.5-4 km east of Goleta Pier, in sea cliffs between Goleta Point and Goleta Beach County Park, in sea cliffs and the intertidal zone south of Isla Vista.

Samples from the lower part of the Sisquoc Formation near Goleta Pier contain diatoms of the Thalassiosira miocenica/ Nitzschia miocenica Assemblage Zone (late Miocene age, about 6.2-6.7 Ma) (J.A. Barron, U.S. Geological Survey, oral and written communs., 2001, 2002). Samples from the upper part of the Sisquoc Formation from a coastal exposure near the University of California, Santa Barbara, yielded diatoms of the Thalassiosira oestrupii Zone (early Pliocene age, younger than $5.5 \mathrm{Ma}$ ) (J.A. Barron, U.S. Geological Survey, oral and written commun., 2005), and diatoms of early Pliocene age have been previously reported from the upper part of the Sisquoc Formation in coastal exposures about $8 \mathrm{~km}$ west of the map area (Arends and Blake, 1986; Blake, 1994, p. 19).

At several localities in the Goleta quadrangle, the contact between the Sisquoc Formation and the underlying Monterey Formation is abrupt and is placed at the base of the stratigraphically lowest thick bed of conglomerate; this lithologic change appears to coincide with boundary between T. miocenica/N. miocenica Assemblage Zone and the underlying Rouxia californica Partial Range Zone (late Miocene age, about 6.7-7.6 Ma) (J.A. Barron, personal commun., 2001) and is interpreted herein as a regional unconformity.

Most rocks mapped in this study as Sisquoc Formation were previously mapped as Monterey Formation (Upson, 1951), unnamed upper Pliocene formation (Upson, 1951), Santa Margarita Shale (Bailey, 1952; Dibblee, 1966), Sisquoc Formation (Dibblee, 1966), and Sisquoc Shale (Dibblee, 1987b). Some rocks previously mapped as Monterey Shale (Dibblee, 1966) and Monterey Formation (Dibblee, 1987b) are herein included in the Sisquoc Formation.

Thickness of the Sisquoc Formation in map area is uncertain because the upper part of the unit was removed by erosion prior to deposition of the overlying Santa Barbara Formation (Qsb), unnamed sedimentary rocks east of Goleta Pier (Qcg, Qss, and QTst), and marine terrace deposits (Qmt). The Sisquoc is at least 250-300 m thick in the Goleta Pier area (Dibblee, 1966, p. 51).

Organic content in Sisquoc is locally great enough for unit to qualify as a potential hydrocarbon source in region (Tennyson and Isaacs, 2001). In certain coastal areas, most notably Isla Vista, wave-aided erosion of sea cliffs underlain by the Sisquoc Formation has undermined buildings and exposed parts of their foundations

Monterey Formation (Miocene)-Marine, predominantly well-bedded, siliceous and calcareous mudstone and shale with subordinate porcelanite and dolomite. The Monterey Formation is well exposed in sea cliffs spanning the eastern two-thirds of the map area; however, the Monterey generally is poorly exposed and highly weathered, with many original 
lithologic details obscured, where it crops out inland in the low hills north of Goleta and in the Hope Ranch area. The Monterey Formation is of Miocene age on the basis of abundant biostratigraphic data from microfossils (Dibblee, 1966; Ingle, 1980, and references therein; Arends and Blake, 1986; Barron, 1986; DePaolo and Finger, 1991; Blake, 1994; Hornafius, 1994a, 1994b, and references therein). The Monterey Formation is about $370-390 \mathrm{~m}$ thick in the sea cliffs about $8 \mathrm{~km}$ west of the map area (Minor and others, in press); elsewhere in the map area, the thickness of the Monterey Formation cannot be reliably determined because of poor and discontinuous exposure, complicated structure, and erosion. The maximum, composite thickness of the formation is estimated to be about $830 \mathrm{~m}$ based on maximum thicknesses of Monterey subunits exposed at several different locations. Organic contents in rocks of the Monterey Formation are generally high and the unit is a major potential hydrocarbon source in the region (Tennyson and Isaacs, 2001). Also, highly fractured zones within the formation form localized oil reservoirs (Tennyson and Isaacs, 2001).

The Monterey Formation is divided into three subunits that are distinguished from each other by lithology and age: an upper siliceous unit, a middle shale unit, and a lower calcareous unit. The upper siliceous unit (Tmu) consists mainly of soft to moderately hard diatomaceous mudstone and shale. The middle shale unit (Tmm) is lithologically diverse and consists of interstratified siliceous and calcareous shale, mudstone, porcelanite, and phosphorite. The lower calcareous unit (Tml) consists mainly of calcareous mudstone and shale. Microfossil assemblages, mainly diatoms, calcareous nannofossils, and benthic foraminifers, indicate that the upper unit is of late Miocene age, the middle unit of late and middle Miocene age, and the lower unit of middle and early Miocene age

Tmu Upper siliceous unit (upper Miocene)—Unit consists mainly of diatomaceous mudstone and shale with subordinate dolomite and porcelanite. Mudstone and shale generally weather white to tan, have a slight red to orange cast in places where hydrocarbon staining is present, and are generally brown to gray on fresh surfaces. The rocks are soft to moderately hard, less resistant to weathering than dolomite and porcelanite, noticeably low density, and locally exhibit numerous fractures coated with abundant jarosite and goethite(?). Variable reactions to dilute $\mathrm{HCl}$ indicate the presence of variable amounts of carbonate minerals. Microfossils are abundant, generally well preserved, and include diatoms, foraminifers, and fish fragments; in places, freshly broken surfaces of diatomaceous mudstone reveal many diatom tests with opaline luster. Mudstone and shale are generally thin to thick bedded and well laminated; the laminations are generally $0.5-20 \mathrm{~mm}$ thick and are defined by color banding ranging from nearly white to dark gray-brown, variations in the types and abundance of microfossils, and parallel alignment of flat 
particles, mainly fish scales and diatom tests. Rarely beds include creamcolored phosphatic laminations and (or) oblate phosphatic nodules as much as $1 \mathrm{~cm}$ thick and $5 \mathrm{~cm}$ long, with the longest dimension usually parallel to bedding. In places, the mudstone and shale exhibit hydrocarbon staining and a strong petroliferous odor.

Dolomite concretions and beds constitute about 5-10 percent of the unit. The concretions are ellipsoidal to spheroidal, generally $10-50 \mathrm{~cm}$ thick and less than $2.5 \mathrm{~m}$ long, and usually oriented with the long axis parallel to stratification. The beds are generally laterally persistent and mostly about $10-100 \mathrm{~cm}$ thick but in places are more than $200 \mathrm{~cm}$ thick. Dolomite is very hard and brittle, relatively resistant, brown to gray on fresh surfaces, generally weathers white with a slight orange or yellow cast, and is aphanitic to sugary in texture. Reaction of the dolomite in dilute $\mathrm{HCl}$ ranges from none to weak. Laminations in the dolomite are common and resemble those in the associated mudstone and shale. In some cases, laminations in dolomitic concretions pass laterally into mudstone and shale. Microfossils, including foraminifers and fish fragments, are abundant in the dolomite but generally poorly preserved. In many places, the dolomite is strongly fractured and in some exposures brecciated; some fractures are filled by white minerals of unknown composition, whereas other fractures are filled by hydrocarbons.

Porcelanite is present only in the stratigraphically lower part of the upper siliceous unit and occurs as isolated, resistant beds about $5-50 \mathrm{~cm}$ thick that are sporadically interstratified with diatomaceous mudstone and shale. The porcelanite is hard and brittle, gray to brown on fresh surfaces, weathers tan to white, is generally noncalcareous, and exhibits conchoidal fracture and porcelaneous luster. The porcelanite is generally well laminated and contains abundant but poorly preserved microfossils, including foraminifers. In places, the porcelanite is strongly fractured and stained by hydrocarbons.

Samples from coastal outcrops of the upper siliceous unit a few kilometers west of the map area and near Goleta Pier yielded benthic foraminiferal assemblages that probably represent the upper part of the Mohnian Stage of Kleinpell $(1938,1980)$ and upper bathyal to upper middle bathyal (150-1500 m) water depths (R.S. Boettcher, written commun., 2001; K.A. McDougall, written commun. 2004), and diatom assemblages of the Rouxia californica Partial Range Zone, Thalassiosira antiqua Zone, and Denticulopsis hustedtii Zone, all of late Miocene age (Barron, 1986; J.A. Barron, written commun., 2001-2005). This data, together with other published and unpublished data from upper Monterey exposures farther west and east of the map area, imply that the base of the upper siliceous unit increases in age from west to east across the region, from about 8.0-8.5 Ma in the vicinity of Dos Pueblos Canyon $8 \mathrm{~km}$ west of the map area (Hornafius, 1994a) to about 9.2-9.9 Ma or older in the Mission Ridge area $5 \mathrm{~km}$ to the east.

The upper siliceous unit rests conformably and sharply on the middle 
shale unit (Tmm). The contact between the two units is well exposed in the sea cliff about $5.4 \mathrm{~km}$ east of Goleta Pier and is placed at base of a prominent $40-\mathrm{cm}$-thick dolomite bed that overlies a prominent horizon of dark platy phosphatic shale that is highest known stratigraphic position of conspicuously phosphatic shale in Monterey Formation in this area.

Small area of siliceous shale on the north side of More Mesa just south of Atascadero Creek questionably assigned to the upper siliceous unit (mapped as Tmu?) owing to very poor exposure and lack of a biostratigraphic age determination.

Rocks assigned herein to the upper siliceous unit previously were mapped as Monterey Shale (Upson, 1951), upper Monterey Shale (Dibblee, 1966), and upper shale unit of the Monterey Formation (Dibblee, 1987b). The thickness of the upper siliceous unit is about $250 \mathrm{~m}$ in the vicinity of Goleta Pier. The upper siliceous unit is well exposed along sea cliffs in the quadrangle, where it forms bright, white-weathering dip slopes; small landslides and rock falls are common along these slopes, but the upper siliceous unit is generally more resistant to erosion and less susceptible to landsliding than the underlying middle shale unit

Tmm Middle shale unit (upper and middle Miocene)—Shale, mudstone, dolomite, porcelanite, phosphorite, and subordinate tuff, typically exposed in white-weathering dip slopes along sea cliffs. Shale and mudstone are variable in outcrop appearance, which reflects varying proportions of siliceous, calcareous, phosphatic, organic, and argillaceous components; some are highly calcareous and react vigorously in dilute $\mathrm{HCl}$, whereas some dark-colored, apparently organic-rich shales react weakly or not at all. Siliceous and calcareous shale and mudstone typically are hard and brittle, commonly fissile to platy weathering, and relatively resistant to weathering; phosphatic, organic-rich, and clay-rich shales and mudstones are generally less hard and less resistant, and range from hackly to fissile weathering. Shale and mudstone generally weather white to tan; some phosphatic-and organic-rich shales and mudstones weather reddish-brown. Shale and mudstone of all compositions are brown to dark brown on fresh surfaces, and commonly are well laminated and thin to medium bedded; most beds are less than $30 \mathrm{~cm}$ thick, but some are $100 \mathrm{~cm}$ thick or more. Most beds are laminated; in places, the laminations show subtle low-angle truncations that probably represent scour-and-fill processes on the sea floor and can be used as top-bottom indicators. Most laminae are planar and parallel to each other but some horizons exhibit small-scale, disharmonic and isoclinal folds that probably represent soft-sediment deformation. In places, shale and mudstone contain abundant microfossils visible with hand lens, including foraminifers and fish scales. Diatoms are visible in the upper part of the unit at certain localities. In places, foraminifers are concentrated in sandy-textured lenses; these lenses fill shallow scours that truncate lamination in the underlying strata and thereby aid in determining the direction of stratigraphic top. Cream- to 
white-colored phosphatic laminae, generally $1-10 \mathrm{~mm}$ thick, and phosphatic nodules up to $5 \mathrm{~cm}$ across, are locally abundant in the shale and mudstone, particularly in darker-colored, less-resistant horizons. Interbeds and concretions of dolomite range in thickness from a few $\mathrm{cm}$ to about $300 \mathrm{~cm}$ and are similar in lithology to dolomite in the upper siliceous unit.

Porcelanite is generally hard and brittle, relatively resistant to erosion, weathers tan or gray to nearly white, is dark gray or dark brown to black on freshly-broken surfaces, shows conchoidal fracture and porcelaneous luster, and exhibits a reaction to dilute $\mathrm{HCl}$ ranging from none to very strong. Most beds are well-laminated and, where observed in large outcrops, persist for tens to hundreds of meters along strike; beds range from a few $\mathrm{cm}$ to about $40 \mathrm{~cm}$ thick, but some beds exceed $100 \mathrm{~cm}$. Laminae of black, glassy chert are present in places. Some beds contain abundant foraminifers and fish scales that are visible with a hand lens. In some inland exposures the foraminifers have been removed by dissolution, leaving behind small holes that preserve the shapes of the foraminifers. In places, porcelanite is strongly fractured, and the fractures are partly or completely filled by dark-colored asphaltic material with a strong petroliferous odor; locally the porcelanite is brecciated.

Tuff is present sporadically as single, laterally-persistent beds, generally $1-5 \mathrm{~cm}$ thick but locally $25 \mathrm{~cm}$, that range from soft and friable to hard, and that weather to a variety of colors including orange, green, cream, gray, and white. The tuff is generally aphanitic but in places exhibits a silty to very fine sandy texture and contains crystals of biotite(?).

A sample from the uppermost part of the middle shale unit about 5.4 $\mathrm{km}$ east of Goleta Pier yielded benthic foraminifers indicative of the Mohnian Stage, possibly upper Mohnian, of Kleinpell $(1938,1980)$ and probable upper middle bathyal (500-1500 m) water depths (R.S. Boettcher, written commun., 2001). Samples from the Hope Ranch area and the Arroyo Burro area $1 \mathrm{~km}$ east of the map area yielded lower Mohnian benthic foraminifers suggestive of middle bathyal (500-2000 m) water depths, as well as calcareous nannofossils of probable late Miocene age (R.S. Boettcher and S.A. Kling, written communs., 2001).

The conformable depositional contact between the middle shale unit and underlying lower calcareous unit (Tml) is not well exposed in the map area. However, this contact is exposed in a sea cliff about $3 \mathrm{~km}$ east of the map area where it is placed at the base of a prominent, thick interval of porcelanite (the "massive chert member" of Hornafius, 1994a, p. 120123). According to Hornafius (1994a, p. 123), the boundary between the Mohnian and Luisian benthic foraminiferal stages is also exposed in this sea cliff just a few meters stratigraphically above the contact and is associated with a prominent, white-weathering dolomite bed.

Rocks mapped as middle shale unit in this report were previously mapped as Monterey Shale (Upson, 1951), upper Monterey Shale 
(Dibblee, 1966), lower Monterey Shale (Dibblee, 1966), and upper shale unit of Monterey Formation (Dibblee, 1987b). The middle shale unit of this report apparently includes all of the middle shale and massive chert members and part or all of upper chert member of Hornafius (1994a, p. 121-122). The thickness of the unit cannot be determined accurately in the map area owing to structural complications and the fact that many exposures are at low angles to bedding. The thickness in the area is estimated to be about $120-180 \mathrm{~m}$.

In coastal exposures in the Goleta quadrangle, the middle shale unit is involved in several large landslides, many of which comprise large translated and partly rotated blocks of internally intact bedrock in which remnants of pre-landslide stratigraphy and structure are preserved (see also Bezore and Wills, 2000). Inland exposures of the middle shale unit, limited to lower Sycamore Canyon, are very poor and the unit is mostly covered by colluvium and vegetation

Tml Lower calcareous unit (middle and lower Miocene) - Calcareous, siliceous, and phosphatic mudstone and shale, with subordinate dolomite, porcelanite, breccia, and tuff. Distinguished from the underlying Rincon Shale (Tr) mainly by its well-bedded character and greater proportion of siliceous shale and mudstone, which typically are harder and more resistant to weathering than Rincon Shale.

Mudstone and shale range from moderately hard to very hard, weather white to tan, and are brown to gray brown on fresh surfaces. Mudstone and shale are well stratified and form laterally persistent beds generally $3-$ $30 \mathrm{~cm}$ thick, but some beds are as thick as $100 \mathrm{~cm}$. Beds vary considerably in relative resistance to weathering. Reaction in dilute $\mathrm{HCl}$ is moderate to strong in most beds, indicating that they are moderately to highly calcareous. Most beds exhibit laminations ranging from 0.5 to $10 \mathrm{~mm}$ thick, which are defined by subtle variations in color and texture; some beds are massive to bioturbated. Microfossils are abundant and consist mainly of calcareous foraminifers and fish fragments. Some beds contain more than 50 percent bioclastic debris. In places, white- to cream-colored phosphatic nodules and laminae are abundant, generally about $1-10 \mathrm{~mm}$ thick and $5-25 \mathrm{~cm}$ in longest dimension, which is always parallel to bedding. Intervals of mudstone with abundant phosphatic nodules and laminae are thicker and more frequent in the upper part of the unit, and in places are as thick as $5 \mathrm{~m}$. These intervals weather white to tan, are dark gray to brown on fresh surfaces, and generally are less resistant to weathering than calcareous and siliceous mudstones.

Dolomite is very hard, resistant, weathers yellow-gray to orange-gray and light orange, and is gray to gray-brown on freshly broken surfaces. Dolomite constitutes less than 5 percent of the unit and generally occurs as beds and concretions about $10-50 \mathrm{~cm}$ thick, but some beds are as thick as $200 \mathrm{~cm}$. Concretions are ellipsoidal to irregular in shape and about 1-2 m in longest dimension, which is usually parallel to stratification. Most 
dolomite reacts slowly with dilute $\mathrm{HCl}$, but some weathered dolomite reacts strongly. Dolomite beds are often strongly fractured; veins of white to gray calcite are common and some veins are oil stained.

Porcelanite is hard, brittle, resistant, exhibits conchoidal fracture, weathers light gray to white, and is gray to brown on freshly broken surfaces. Porcelanite is present at irregular intervals in the unit as massive to well-laminated beds about $5-20 \mathrm{~cm}$ thick that increase in thickness and abundance upward in the unit. The relative amount of porcelanite is generally less than one percent but locally is as much as 25 percent. In some exposures, porcelanite contains small holes created by dissolution of calcareous foraminifers.

Tuff constitutes much less than one percent of the unit. It weathers orange-gray to yellow-gray, is gray to greenish-gray on freshly broken surfaces, and ranges from vitric to crystal-vitric with crystals of biotite and feldspar. In general tuff forms laterally persistent, recessive beds about $1-$ $10 \mathrm{~cm}$ thick; the lower bed contacts are generally sharp and apparently erosional, whereas the upper contacts are mostly bioturbated and grade into overlying calcareous mudstones. Some crystal-bearing beds of tuff are well laminated and normally graded.

Abundant biostratigraphic, paleomagnetic, and strontium-isotopic data indicate that the lower calcareous unit exposed in sea cliffs about $8 \mathrm{~km}$ west of map area is early middle to early Miocene in age (DePaolo and Finger, 1991; Blake, 1994; Hornafius, 1994a, 1994b). Samples of mudstone and shale from the unit exposed in a sea cliff about $3 \mathrm{~km}$ west of the map area yielded benthic foraminifers indicative of the Relizian and Luisian Stages of Kleinpell $(1938,1980)$ and lower middle bathyal to upper middle bathyal (500-2000 m) water depths (R.S. Boettcher, written commun., 2002; K.A. McDougall, written commun., 2004) and calcareous nannofossils of middle Miocene zone CN5A (S.A. Kling, written commun., 2002). Samples of mudstone from the lower calcareous unit near Santa Barbara Point about $7 \mathrm{~km}$ east of the map area yielded benthic foraminiferal assemblages indicative of the Relizian and Luisian Stages of Kleinpell $(1938,1980)$ and lower middle bathyal to lower bathyal $(>1500$ $\mathrm{m}$ ) water depths, calcareous nannofossils of lower middle Miocene zone $\mathrm{CN} 4$, and apparently reworked early Miocene or late Oligocene calcareous nannofossils (R.S. Boettcher and S.A. Kling, written commun., 2001).

In most of the map area the contact between the lower calcareous unit and the underlying Rincon Shale is not well exposed.

Strata mapped as the lower calcareous unit in this report were previously mapped as Monterey Shale by Upson (1951), lower Monterey Shale by Dibblee (1966), and lower shale unit of Monterey Formation by Dibblee (1987b). The lower calcareous unit of this report is correlative with most or the entire lower calcareous shale member of Hornafius (1994a, p. 121-122; 1994b, p. 6). In map area, the unit crops out only inland in canyons and low uplands. In Goleta quadrangle the unit 
thickness cannot be reliably determined because of typical poor, discontinuous exposures and (or) structural complications, but unit is estimated to be over $400 \mathrm{~m}$ thick in the Hope Ranch area. The thickness of the lower calcareous unit has been accurately determined to be about 250 $\mathrm{m}$ about $8 \mathrm{~km}$ west of the map area (Hornafius, 1994b, p. 4-5)

$\operatorname{Tr} \quad$ Rincon Shale (lower Miocene)_-Marine, primarily massive and thickbedded mudstone, with subordinate dolomite, siliceous shale, sandstone, and tuff. More than 90 percent of the Rincon Shale is composed of mudstone that is gray to gray-brown on freshly broken surfaces, weathers light brown, is generally hard to moderately hard, and generally shows a moderate to weak reaction in dilute $\mathrm{HCl}$. At places, the mudstone contains abundant microfossils including calcareous foraminifers and fish scales. Mudstone is generally massive and bioturbated. It is thick to very thick bedded, with beds generally $30-200 \mathrm{~cm}$ thick. Typical hackly fractures in mudstone commonly contain yellow jarosite.

Dolomite is hard, resistant to weathering, gray to gray brown on freshly broken surfaces, weathers orange to yellow orange, has aphanitic to sugary texture, and reacts slowly or not at all in dilute $\mathrm{HCl}$. Dolomite forms laminated to massive, laterally-persistent beds as thick as $100 \mathrm{~cm}$, and also spheroidal to ellipsoidal concretions that range in size from a few centimeters to nearly $3 \mathrm{~m}$ across. The long axes of the dolomite concretions commonly parallel bedding.

Uncommon sandstone forms sparse interbeds within thick sequences of mudstone. The sandstone is medium to fine grained, feldspathic, and friable. Sandstone beds, generally $5-10 \mathrm{~cm}$ thick and laterally persistent, exhibit sharp and irregular lower contacts that probably represent filled scours in the underlying mudstone and bioturbated upper contacts that grade into the overlying mudstone.

White-weathering tuff in the upper part of the Rincon Shale is exposed at several localities a few kilometers west and east of the map area. Although the inland, generally poor, exposures of the Rincon preclude determination of the tuffs' presence in the Goleta quadrangle, it is likely that it is present discontinuously throughout the coastal plain region. The tuff ranges from soft and friable to moderately indurated, consists mainly of glass shards, and in places contains fish scales as well as pumice and crystals of feldspar, quartz, and biotite. The tuff is massive to welllaminated and its apparent thickness ranges from at least $4 \mathrm{~m}$ to nearly 10 $\mathrm{m}$ based on two localities in the Mission Ridge area in Santa Barbara (Minor and others, in press). Dibblee (1966, p. 46) apparently considered the widely-separated outcrops of tuff in the region to represent a single stratigraphic horizon that marks the base of the Monterey Formation. However, we mapped the boundary between the Rincon Shale and Monterey Formation instead at the lithologic transition from relatively massive and poorly bedded, predominantly argillaceous mudstone (typical of the Rincon Shale), to overlying, well-bedded, siliceous and calcareous 
mudstone and shale (typical of the Monterey Formation). In many places this contact is approximately located because of poor exposure, but tuff exposed near the mouth of Las Varas Canyon about $9 \mathrm{~km}$ west of the map area is clearly at least $8 \mathrm{~m}$ (Hornafius, 1994, p. 6) stratigraphically below the change in lithology and is, thus, included in the Rincon Shale. In places, the tuff may be entirely within the Monterey Formation, as appears to be the case near Lauro Canyon Dam about $2 \mathrm{~km}$ east of the map area. Outcrop quality and available age control are insufficient to demonstrate whether the widely-separated outcrops of tuff represent a single stratigraphic horizon that was deposited during a single event (Dibblee, 1966) or, alternatively, several closely-spaced stratigraphic horizons that were deposited during multiple events. About $13 \mathrm{~km}$ east of the map area, samples of tuff from the Summerland area yielded ${ }^{40} \mathrm{Ar} /{ }^{39} \mathrm{Ar}$ incremental heating and $\mathrm{K}-\mathrm{Ar}$ ages ranging from 16.5 to $17.3 \mathrm{Ma}$ (R.J. Fleck, U.S. Geological Survey, written commun., 2005; Turner, 1970, corrected for changes in decay constants using method of Dalrymple, 1979). A sample of tuff from a coastal exposure about $9 \mathrm{~km}$ west of the map area yielded a ${ }^{40} \mathrm{Ar}{ }^{39} \mathrm{Ar}$ single-crystal laser-fusion age of $18.42 \pm 0.06 \mathrm{Ma}$ (Stanley and others, 1996). Samples of tuff from the northern Santa Barbara area are undated but are petrographically and geochemically indistinguishable from each other (A.M. Sarna-Wojcicki, U.S. Geological Survey, written commun., 2002) and probably were derived from the same eruptive source.

The age of the Rincon Shale is early Miocene on the basis of abundant biostratigraphic evidence from a measured stratigraphic section in Cañada de la Pila, about $15 \mathrm{~km}$ west of the map area (Stanley and others, 1992, 1994) and isotopic ages of tuffs, as noted above. Also, the base of the Rincon Shale is considered to be coincident with the Oligocene-Miocene boundary (D. Bukry, U.S. Geological Survey, oral commun., 1994). The Rincon Shale rests abruptly and conformably on the upper Oligocene Vaqueros Formation and is conformably overlain by the middle and lower Miocene lower calcareous unit of the Monterey Formation.

Unit was previously mapped as Rincon Shale by Upson (1951) and Dibblee (1966, 1987b). The Rincon Shale is about $400 \mathrm{~m}$ thick where the entire unit is exposed in the northwestern part of the map area. The unit is generally poorly exposed and covered by vegetation, and it is susceptible to landsliding (Bezore and Wills, 2000)

Trs Siliceous shale interval (lower Miocene) - Siliceous shale is pale-gray and light-tan on freshly broken surfaces, weathers white to pale-gray, thinbedded, and hard. Unit is slightly more resistant than surrounding Rincon mudstones and resembles siliceous shale intervals within Monterey Formation. Siliceous interval is differentiated only in westernmost part of map area (west of San Pedro Creek and 1-2 km north of Highway 101) where it has a thickness of 35 to $45 \mathrm{~m}$. Unit is about $60 \mathrm{~m}$ stratigraphically 
below top of Rincon Shale a few kilometers west of the map area (Minor and others, in press)

Tv Vaqueros Formation (upper Oligocene)-Shallow marine sandstone; tan, yellowish-tan, yellowish-gray, and greenish-gray, weakly to moderately indurated, and feldspathic. Unit is moderately to strongly resistant to erosion and locally forms prominent ledges, cliffs and ridges; commonly weathers to light-tan rounded sandstone outcrops and distinctive, light-tan sandy soils; some outcrops exhibit cavernous weathering. Sandstone is primarily massive to thick bedded and medium to coarse grained, but becomes finer grained up section; massive sandstone is mostly bioturbated. Some sandstone intervals are very coarse grained and pebbly and others are rich in shell fragments. Sandstone locally contains planar to cross laminations and rare thin $(5-15 \mathrm{~mm})$ partings of gray siltstone and mudstone. Uppermost part contains well-defined, thinly laminated sandstone, siltstone, and mudstone interbeds. Sandstone in upper third of unit commonly is mottled tan and greenish gray; underlying sandstone has abundant orange to red staining and mottling. Fractures commonly contain iron-oxide minerals. In thin section, sandstone consists primarily of quartz and subordinate feldspar and lithic grains (mostly chert and felsic volcanic rock) in an argillaceous matrix or calcite cement. The base of unit is typically marked by a distinctive 50-150-cm-thick, well-indurated and flaggy, thinly bedded and laminated, light-gray, calcareous conglomerate containing abundant pelecypod shell fragments, rounded chert pebbles, and subangular graywacke clasts as long as about $1 \mathrm{~cm}$; chert and graywacke are thought to be derived from the north from Franciscan Complex terrane (Rigsby, 1998). This conglomerate is locally as much as $5 \mathrm{~m}$ above the base of the Vaqueros.

The basal contact is sharp and recognized by abrupt change from thick tan-yellow sandstone and basal gray shell-rich conglomerate of the marine Vaqueros to underlying interbedded light- greenish-gray, tabular sandstone and maroon to olive-gray mudstone of the terrestrial Sespe. Howard (1995) considered the lower Vaqueros contact to be an erosional disconformity throughout the map area, but Rigsby (1998) interpreted an eastward transition of the contact to conformable near Lauro Canyon about $2 \mathrm{~km}$ east of Goleta quadrangle.

Late Oligocene age is inferred from stratigraphic position of unit between the upper Oligocene upper part of Sespe Formation and lower Miocene Rincon Shale. The base of the overlying Rincon Shale is considered to be coincident with the Oligocene-Miocene boundary (D. Bukry, oral commun., 1994). Rigsby (1998) reported a strontium isotope date of $24 \pm 1 \mathrm{Ma}$ from oyster shells in Vaqueros Formation in Hollister Ranch area about $50 \mathrm{~km}$ west of map area, consistent with late Oligocene age.

Unit was previously mapped as Vaqueros Sandstone by Upson (1951) and Dibblee $(1966,1987 b)$. In the map area unit gradually decreases in thickness eastward from about $140 \mathrm{~m}$ to less than $100 \mathrm{~m}$; a regional 
thickness of about $100 \mathrm{~m}$ was reported by Dibblee (1982). Some oil in the region is produced from Vaqueros sandstone reservoirs (Tennyson and Isaacs, 2001)

Sespe Formation (Oligocene and upper Eocene) - Nonmarine fluvial sandstone, mudstone, and conglomerate; predominantly maroon, reddishbrown, and greenish- to pinkish-gray. Sespe Formation is poorly to moderately exposed primarily in northern part of map area in foothills of the Santa Ynez Mountains. In map area, Sespe Formation is divided into three subunits that are distinguished from each other mainly by differences in lithology and age: an upper sandstone and mudstone unit (Tspu), a middle conglomerate and sandstone unit (Tspm), and a lower conglomerate and sandstone unit (Tspl). A major distinguishing feature of the upper unit is its lack of conglomerate, whereas the conglomeratic middle and lower units are distinguished mainly by their differing clast compositions and colors of weathered sandstone and conglomerate beds (mostly maroonish shades in middle unit and pinkish-gray shades in lower unit). The upper unit comprises well over half of the total thickness of formation, and at the eastern boundary of map area the lower two units pinch out so that the upper Sespe rests directly on rocks of the underlying Coldwater Sandstone (Tcw). Overall thickness of Sespe Formation increases eastward across the Goleta quadrangle from about $700 \mathrm{~m}$ to $1,300 \mathrm{~m}$. Some oil in the region is produced from Sespe sandstone and conglomerate reservoirs (Tennyson and Isaacs, 2001).

Age of Sespe Formation in Goleta area is considered late Eocene and Oligocene by Howard (1995), with an intraformational unconformity representing much or all of early Oligocene time. This unconformity (erosional disconformity) coincides with the mapped contact separating the lower conglomerate and sandstone unit (Tspl) from the middle conglomerate and sandstone unit (Tspm). Rocks below unconformity have been interpreted as part of an upper Eocene to lowermost Oligocene fluvial sequence composed of clastic detritus derived primarily from bedrock now exposed in the Mojave Desert, whereas overlying rocks have been interpreted as part of a lower(?) and upper Oligocene fluvial sequence containing chert, graywacke, and other clasts derived from Franciscan Complex source terrane (Howard, 1995)

Tspu Upper sandstone and mudstone unit (upper Oligocene) - Sandstone, siltstone, and mudstone interbedded in proportions that vary both laterally and through the section; sandstone to mudstone-siltstone ratio in a given exposure typically ranges from 5:1 to $1: 5$. Sandstone-rich units are commonly broadly lenticular and thin to thick bedded, and in places they appear to occupy paleochannels. Sandstone beds are as thick as $10 \mathrm{~m}$ but mostly less than $2 \mathrm{~m}$. Sandstone is mostly fine to medium grained, silty, and feldspathic, and locally arkosic. On weathered surfaces sandstones display various shades of maroon, buff, pale green, tan, and gray. 
Horizontal lamination and cross lamination, including trough cross lamination, are common. Sandstone is friable to well indurated and typically forms resistant tabular, flaggy, or ledgy outcrops. Small pebbly lenses are locally present in sandstone beds, and some thin $(\leq 1 \mathrm{~m}$ thick) intervals, commonly near the base of beds, contain subrounded mudstone rip-up clasts as long as $30 \mathrm{~cm}$.

Mudstone is typically silty to sandy and locally grades into siltstone and, rarely, fine-grained sandstone. Mudstone and siltstone are typically maroon, reddish maroon, and brownish maroon, but in some places they are pale green or olive green. Mudstone is thin to very thin bedded and commonly laminated. Intervals of nearly pure mudstone range from less than $10 \mathrm{~cm}$ to at least $10 \mathrm{~m}$ thick. Mudstone and siltstone bedding planes commonly contain mud cracks and ripple marks. Mudstone exhibits hackly to spheroidal fracturing on weathered surfaces. Most mudstonerich intervals are poorly exposed and form gentle slopes.

Late Oligocene age of upper unit is based on Arikareean vertebrate fossils reported from the underlying middle unit in and near the map area (Weaver and Kleinpell, 1963; Howard, 1995) and on the MioceneOligocene boundary recognized at the base of the Rincon Shale (Tr) farther up section (D. Bukry, oral commun., 1994).

Environment of deposition of Sespe upper sandstone and mudstone unit, which is equivalent to lithofacies D of Howard (1995), has been interpreted as progressing upward from braided to meandering river channels and interchannels (Howard, 1995). Unit was previously mapped as part of the Sespe Formation by Upson (1951) and Dibblee (1966, 1987b). Upper unit markedly thickens eastward across map area from about $550 \mathrm{~m}$ to $1,300 \mathrm{~m}$. Upper Sespe unit is prone to landsliding particularly on steeper slopes along the lower flank of the Santa Ynez Mountains as evidenced by numerous slumps and debris-flow deposits in this area

Tspm Middle conglomerate and sandstone unit (Oligocene) - Conglomerate, sandstone, and mudstone interbedded in proportions that vary both laterally and through the section; relative proportion of conglomerate increases down section towards base of unit, but conglomerate is strongly subordinate to sandstone and mudstone in some intervals. Conglomeratic depositional units range from laterally extensive to narrowly lenticular and thin to thick bedded (as thick as $15 \mathrm{~m}$ ), and in some places they appear to occupy paleochannels. Conglomerate and conglomeratic sandstone typically contain subangular to well-rounded pebbles and cobbles supported in a medium- to coarse-grained sandy matrix. Clasts are polymict and include abundant chert and lithic sandstone derived from Franciscan Complex terrane, arkosic sandstone derived from Coldwater Sandstone, and quartzitic, metamorphic, and granitoid rocks derived from Mojave Desert terrane (Howard, 1995). Sandstone is mostly medium to coarse grained, pebbly, silty, and feldspathic to lithic; rare sandstone beds 
are arkosic. On weathered surfaces conglomerates and sandstones display various shades of maroon and, less commonly, tan and pale greenish gray. Horizontal lamination and cross lamination, including trough cross lamination, are common, particularly in sandstones. Sediment-filled fossil burrows are apparent on some sandstone bedding planes. Commonly conglomerates and sandstones are moderately indurated and resistant and form tabular, flaggy, or ledgy outcrops.

Mudstone is typically silty to sandy and locally grades into siltstone and, more rarely, fine-grained sandstone. Mudstone is thin to very thin bedded and commonly laminated. Ripple marks are common. Mudstonerich intervals range in thickness from thin partings to $20 \mathrm{~m}$. Mudstone is maroon, maroonish red, reddish brown, and, rarely, pale greenish-gray and exhibits hackly to spheroidal fracturing on weathered surfaces. Most mudstone-rich intervals are poorly exposed and form gentle slopes.

Upper contact of middle unit mapped at stratigraphically highest conglomerate bed. Disconformity at base of middle unit commonly expressed by abrupt change from maroonish sandstone and conglomerate of mixed provenance (middle unit) to pale-pinkish-gray, sandstone and conglomerate of largely granitic and metamorphic provenance (lower Sespe unit).

Middle conglomerate and sandstone unit is primarily equivalent to Sespe lithofacies C of Howard (1995). Oligocene age of middle unit is based on Arikareean vertebrate fossils (Sespia nitida Leidy) that were reported from the unit above unconformity along San Marcos Pass highway and in Sycamore Canyon (about $7 \mathrm{~km}$ east of map area) (Weaver and Kleinpell, 1963; Howard, 1995).

Middle unit was previously mapped as part of the Sespe Formation by Upson (1951) and Dibblee (1966, 1987b), and as red to gray conglomerate and arkosic sandstone of the Sespe Formation by Dibblee (1987b). Middle unit generally increases in thickness eastward across map area from about $200 \mathrm{~m}$ to $250 \mathrm{~m}$, but unit locally thins and pinches out over a strike distance of more than $1.8 \mathrm{~km}$ spanning the eastern border of quadrangle (Minor and others, in press). Unit is moderately susceptible to landsliding particularly on steeper slopes along the lower flank of the Santa Ynez Mountains as evidenced by several small slumps in that area Eocene) - Conglomerate, conglomeratic sandstone, sandstone, mudstone, and minor shale interbedded in proportions that vary both laterally and through the section. Conglomeratic depositional units range from laterally extensive to narrowly lenticular and medium to thick bedded (as thick as $15 \mathrm{~m}$ ), and in some places they appear to occupy paleochannels. Conglomerate and conglomeratic sandstone typically contain pebbles and cobbles as much as $50 \mathrm{~cm}$ in diameter supported in a medium-grained to very coarse-grained, locally arkosic sandstone matrix. Clasts are polymict and include abundant subrounded to well-rounded quartzitic, granitoid, 
metamorphic, and volcanic clasts derived from Mojave Desert terrane and lesser subangular to subrounded arkosic sandstone clasts and rare oystershell fragments and shale clasts derived from Coldwater Sandstone (Tcw) (Howard, 1995). Sandstone is mostly medium to very coarse grained, pebbly, feldspathic, and locally arkosic. On weathered surfaces conglomerates and sandstones mostly exhibit distinctive shades of salmon gray, reddish gray, pale-pinkish gray, and tan, but some beds are pale gray, maroon, or brown; reddish-brown iron-oxide staining is locally prevalent. Horizontal lamination and cross lamination, including trough cross lamination, are very common, particularly in sandstones.

Conglomerates and sandstones are moderately to well indurated, resistant, and form flaggy, blocky, and ledgy outcrops and hogbacks.

Mudstone is typically silty to sandy and locally grades into siltstone and, more rarely, fine-grained sandstone. Intervals of fissile shale are locally present. Mudstone is thin to very thin bedded and commonly laminated. Mudstone-rich intervals range in thickness from thin partings to $5 \mathrm{~m}$. Mudstone is maroon, maroonish red, gray, greenish-gray, and reddish brown and exhibits hackly to spheroidal fracturing on weathered surfaces. Most mudstone-rich intervals are poorly exposed and form gentle slopes.

Disconformable upper contact of lower conglomerate and sandstone unit mapped at top of 3-10-m-thick interval of conspicuous deep-reddishbrown, massive-to-bedded, silty to sandy claystone and mudstone. Basal, mostly conformable, contact of lower unit mapped at generally sharp change from pinkish- and reddish-gray laminated sandstone and conglomerate (Sespe) to pale yellow-tan to buff, massive, commonly oyster-shell-bearing sandstone of the underlying Coldwater Sandstone (Tcw).

Overall grain size of lower unit becomes somewhat finer in northwest part of map area, and at Bartlett Canyon lower unit has been previously interpreted to grade westward into marine sandstone of the upper Eocene and lowermost Oligocene (Refugian) Gaviota Formation (Weaver and Kleinpell, 1963; Howard, 1995). However, correlation of lower Sespe beds with Gaviota in this area is questionable due to fault complications (as noted in Weaver and Kleinpell, 1963) and because clear marine, fossilbearing interbeds were not observed within the lower unit during our mapping. Possibly the lower Sespe transition into the Gaviota is confined to the small area where the lower conglomerate and sandstone unit pinches out in Glen Annie Canyon just west of map area. The locally gradational nature of the basal Sespe contact with the underlying Coldwater Sandstone is consistent with a late Eocene age for part or all of the lower conglomerate and sandstone unit.

The lower unit is primarily equivalent to Sespe lithofacies A of Howard (1995). Unit was previously mapped as part of the Sespe Formation by Upson (1951) and Dibblee $(1966,1987 b)$ and as red to pink (or pink to white) sandstone and red claystone of the Sespe Formation by 
Dibblee (1987b). The lower conglomerate and sandstone unit increases in thickness eastward along strike across map area from where it pinches out in Glen Annie Canyon about $1 \mathrm{~km}$ west of map area to about $150 \mathrm{~m}$ near San Antonio Creek, but farther east the unit abruptly thins and pinches out along a short strike distance spanning the eastern border of quadrangle

Tcw Coldwater Sandstone (upper? and middle Eocene)—Shallow marine sandstone with subordinate interbeds and thin intervals of siltstone, shale, and mudstone. Sandstone is mostly fine- to medium-grained, feldspathic and partly arkosic, locally silty to clayey or micaceous, and locally weakly cemented with calcium carbonate. Sandstone forms thin, tabular beds as well as medium to thick beds, some of which are massive and bioturbated whereas others contain planar, wavy, or cross laminations. Thin siltstone and shale partings are rare in the sandstones. Sandstone is typically pale gray and greenish gray on fresh surfaces and weathers to distinctive, pale shades of buff, yellowish-tan, tan, and brown. Some beds and intervals as thick as $3 \mathrm{~m}$ especially in the upper part of the unit contain rare to conspicuously abundant oyster shells and shell fragments (Ostrea idriaensis, Weaver and Kleinpell, 1963), and numerous other fossil mollusks have been previously identified throughout the unit (e.g., Weaver and Kleinpell, 1963). Other beds and intervals contain rare to abundant ferruginous(?) fossil wood fragments that commonly contrast visually with the surrounding rock due to their dark-gray to reddish-brown color. Local lenses and intervals as thick as $25 \mathrm{~m}$ of conglomeratic sandstone are present in the uppermost Coldwater near its contact with the overlying lower unit of the Sespe Formation (Tspl). Evidence of localized soft-sediment deformation consists of contorted and disrupted layering in some sandstone beds. Sandstone beds and sandstone-rich intervals typically crop out as resistant, blocky ledges and cliffs and form prominent hogbacks where steeply dipping.

Siltstone, shale, and mudstone form interbeds as thin as $1 \mathrm{~cm}$ and bedded intervals as thick as $5 \mathrm{~m}$. These fine-grained rocks mostly exhibit pale to dark shades of gray, olive-gray, and greenish-gray. Commonly shale is fissile and mudstone exhibits hackly fractures. Some siltstone beds are micaceous and contain fossil wood fragments. Siltstones and finer-grained rocks of the Coldwater are considerably less resistant than the sandstones and tend to be more poorly exposed than the sandstones.

Age of unit is not tightly constrained in map area; regionally, age of Coldwater has been variably considered late and (or) middle Eocene (Narizian) (Kleinpell and Weaver, 1963; Dibblee, 1966; Howard, 1995; Campion and others, 1996; Prothero, 2001) on basis of paleontologic, magnetostratigraphic, and sequence stratigraphic correlations. Uppermost part of map unit in northwest part of map area may include eastwardterminating sandstone-rich beds of the marine upper Eocene and lowermost Oligocene (Refugian) Gaviota Formation that closely resemble 
sandstones of the underlying Coldwater (Weaver and Kleinpell, 1963; Dibblee, 1966, 1987b).

Unit was previously mapped as Tejon Formation by Upson (1951), as "Coldwater" Sandstone by Dibblee (1966), and as Coldwater Sandstone by Dibblee (1987b). Base of Coldwater is not exposed in map area; unit is about 750 to $1,000 \mathrm{~m}$ thick regionally (Dibblee, 1982). Unit forms elevated, rugged ridges, spurs, and hogbacks on the steep, southern flank of the Santa Ynez Mountains. Several large landslide deposits in the Coldwater in the map area indicate susceptibility of the unit to slope failure 


\section{ACKNOWLEDGMENTS}

The present mapping effort was funded by the USGS National Cooperative Geologic Mapping Program's Southern California Areal Mapping Project (SCAMP) and Basin and Landscape Evolution Project (BALANCE). The unwavering support of SCAMP chief Doug Morton allowed our coastal plain mapping efforts to continue smoothly to their completion. We are grateful to Chuck Powell and John Barron (both USGS) for their numerous and important paleontologic and biostratigraphic contributions to our mapping efforts. We thank Jim Messerich of the USGS Laboratory for Geologic Photogrammetry and Digital Mapping in Denver for his professional photogrammetric support. Constructive reviews by Dave Moore, David Sawyer, and Jeremy Workman improved the quality of the map, map text, and map database. Numerous discussions and sharing of geologic concepts in and out of the field with Larry Gurrola and Ed Keller of the tectonic geomorphology research group at the University of California at Santa Barbara greatly improved our understanding and interpretation of the coastal geology and Quaternary geologic evolution of the map area. Larry also kindly provided critical information regarding private-land ownership and access and geotechnical data in the map area. Finally, the late Tom Dibblee is due special acknowledgment for his earlier geologic mapping in the Santa Barbara coastal plain region that formed an invaluable foundation for our new mapping efforts.

\section{REFERENCES CITED}

Addicott, W.O., 1965, Some western American Cenozoic gastropods of the genus Nassarius: U.S. Geological Survey Professional Paper 503B, p. B1-B24.

Arends, R.G., and Blake, G.H., 1986, Biostratigraphy and paleoecology of the Naples Bluff coastal section based on diatoms and benthic foraminifera, in Casey, R.E., and Barron, J.A., eds., Siliceous microfossil and microplankton studies of the Monterey Formation and modern analogs: Los Angeles, Society of Economic Paleontologists and Mineralogists, Pacific Section, Book 45, p. 121-135.

Bailey, T.L., 1952, Review [of "Geology of Southwestern Santa Barbara County, California," by T.W. Dibblee, Jr.]: American Association of Petroleum Geologists Bulletin, v. 36, no. 1, p. 176-178.

Barron, J.A., 1986, Updated diatom biostratigraphy for the Monterey Formation of California, in Casey, R.E., and Barron, J.A., eds., Siliceous microfossil and microplankton studies of the Monterey Formation and modern analogs: Society of Economic Paleontologists and Mineralogists, Pacific Section, Book 45, p. 105-119.

Bezore, S., and Wills, C.J., 2000, Landslide hazard maps of southeastern Santa Barbara County, California: California Division of Mines and Geology Open-File Report 99-12, 4 sheets, scale 1:24,000. 
Blake, G.H., 1994, Detailed biostratigraphy and paleoenvironmental interpretation of the Naples Bluff section, in Hornafius, J.S., ed., Field guide to the Monterey Formation between Santa Barbara and Gaviota, California: Bakersfield, Calif., Pacific Section, American Association of Petroleum Geologists, p. 17-28.

Campion, K.M., Sullivan, M.D., May, J.A., and Warme, J.E., 1996, Sequence stratigraphy along a tectonically active margin, Paleogene of southern California, in Abbott, P.L., and Cooper, J.D., eds., Field Conference Guide 1996: American Association of Petroleum Geologists, Pacific Section, GB 73, and Society for Sedimentary Geology (SEPM), Pacific Section, Book 80, p. 125-187.

Cruden, D.M., and Varnes, D.J., 1996, Landslide types and processes, in Turner, A.K., and Schuster, R.L., eds., Landslides investigations and mitigation: Washington, D.C., National Academy Press, p. 36-75.

Dalrymple, G.B., 1979, Critical tables for conversion of K-Ar ages from old to new constants: Geology, v. 7, no. 11, p. 558-560.

DePaolo, D.J., and Finger, K.L., 1991, High resolution strontium isotope stratigraphy and biostratigraphy of the Miocene Monterey Formation, central California: Geological Society of America Bulletin, v. 103, no. 1, p. 112-124.

Dibblee, T.W., Jr., 1966, Geology of the central Santa Ynez Mountains, Santa Barbara County, California: California Division of Mines and Geology Bulletin 186, 99 p.

Dibblee, T.W., Jr., 1982, Geology of the Santa Ynez-Topatopa Mountains, Southern California, in Fife, D.L., and Minch, J.A., eds., Geology and mineral wealth of the California Transverse Ranges: Santa Ana, California, South Coast Geological Society Annual Symposium and Guidebook no. 10, p. 41-56.

Dibblee, T.W., Jr., 1986a, Geologic map of the Carpinteria quadrangle, Santa Barbara County, California: Santa Barbara, California, Dibblee Geological Foundation Map DF-04, scale 1:24,000.

Dibblee, T.W., Jr., 1986b, Geologic map of the Santa Barbara quadrangle, Santa Barbara County, California: Santa Barbara, California, Dibblee Geological Foundation Map DF-06, scale 1:24,000.

Dibblee, T.W., Jr., 1987a, Geologic map of the Dos Pueblos quadrangle, Santa Barbara County, California: Santa Barbara, California, Dibblee Geological Foundation Map DF-09, scale 1:24,000.

Dibblee, T.W., Jr., 1987b, Geologic map of the Goleta quadrangle, Santa Barbara County, California: Santa Barbara, California, Dibblee Geological Foundation Map DF-07, scale 1:24,000. 
Dickinson, W.R., 1995, Paleogene depositional systems of the western Transverse Ranges and adjacent southernmost Coast Ranges, California, in Fritsche, A.E., ed., Cenozoic Paleogeography of the western United States II: Santa Fe Springs, Calif., Pacific Section SEPM (Society for Sedimentary Geology), p. 53-83.

Gurrola, L.D., Selting, A.J., Keller, E.A., Tierney, T.E., Hartleb, R.D., Trecker, M.A., and Dibblee, T.W., Jr., 2001, Neotectonics of the Santa Barbara fold belt, California, with a section on Investigation of the Mission debris flow deposit, Santa Barbara, California, by A.J. Selting, A.J. and R.J. Urban, in Dunne, G., and Cooper, J., compilers, Geologic excursions in southwestern California: Society of Economic Paleontologists and Mineralogists, Pacific Section, Book 89, p. 21-100.

Hill, M.L., 1932, Mechanics of faulting near Santa Barbara, California: Journal of Geology, v. 40, n. 6, p. 535-556.

Hoover, M.F., 1978, Geologic hazards evaluation of the City of Santa Barbara to Rincon Point, California: San Diego, California, California State University, M.S. thesis, 91 p.

Hornafius, J.S., 1994a, Field trip road log to the Monterey Formation between Santa Barbara and Gaviota, California, in Hornafius, J.S., ed., Field guide to the Monterey Formation between Santa Barbara and Gaviota, California: Bakersfield, Calif., Pacific Section, American Association of Petroleum Geologists, p. 107-123.

Hornafius, J.S., 1994b, Overview of the stratigraphy of the Monterey Formation along the coastline between Santa Barbara and Gaviota, California, in Hornafius, J.S., ed., Field guide to the Monterey Formation between Santa Barbara and Gaviota, California: Bakersfield, Calif., Pacific Section, American Association of Petroleum Geologists, p. $1-15$.

Hornafius, J.S., Luyendyk, B.P., Terres, R.R., and Kamerling, M.J., 1986, Timing and extent of Neogene tectonic rotation in the western Transverse Ranges, California: Geological Society of America Bulletin, v. 97, p. 1476-1487.

Howard, J.L., 1995, Conglomerates of the upper middle Eocene to lower Miocene Sespe Formation along the Santa Ynez Fault-Implications for the geologic history of the eastern Santa Maria basin area: U.S. Geological Survey Bulletin 1995-H, p. H1-H36.

Ingle, J.C., Jr., 1980, Cenozoic paleobathymetry and depositional history of selected sequences within the southern California continental borderland: Cushman Foundation Special Publication 19, Memorial to Orville Bandy, p. 163-195.

Izett, G.A., Naeser, C.W., and Obradovich, J.D., 1974, Fission-track age of zircons from an ash bed in the Pico Formation (Pliocene and Pleistocene) near Ventura, California [abs.]: Geological Society of America, Annual Meeting, Cordilleran Section, Program with Abstracts, p. 197. 
Keller, E.A., and Gurrola, L.D., 2000, Final report, July, 2000, Earthquake hazard of the Santa Barbara fold belt, California: online at http://www.scec.org/research/98research/98gurrolakeller.pdf.

Kleinpell, R.M., 1938, Miocene stratigraphy of California: Tulsa, Okla., American Association of Petroleum Geologists, $450 \mathrm{p}$.

Kleinpell, R.M., 1980, History of stratigraphic paleontology of west coast Tertiary, in Kleinpell, R.M., and others, The Miocene stratigraphy of California revisited: Tulsa, Okla., American Association of Petroleum Geologists Studies in Geology no. 11, p. 4 53.

Kleinpell, R.M., and Weaver, D.W., 1963, Oligocene biostratigraphy of the Santa Barbara embayment, California: University of California Publications in Geological Sciences, v. 43,250 p.

Luyendyk, B.P., 1991, A model for Neogene crustal rotations, transtension, and transpression in southern California: Geological Society of America Bulletin, v. 103, n. 11, p. $1528-1536$.

McDougall, Kristin, and Lagoe, M.B., 1993, Foraminiferal data from the Balcom Canyon Section, Ventura Basin, California: U.S. Geological Survey Open-file Report 93-386, $132 \mathrm{pp}$.

Minor, S. A., Kellogg, K. S., Stanley, R. G., Stone, P., Powell, C. L., I.I., Gurrola, L. D., Selting, A. J., and Brandt, T. R., 2002, Preliminary geologic map of the Santa Barbara coastal plain area, Santa Barbara County, California: U.S. Geological Survey OpenFile Report 02-0136, 22 p., scale 1:24,000. (Available online at: http://pubs.usgs.gov/of/2002/ofr-02-0136/)

Minor, S. A., Kellogg, K. S., Stanley, R. G., Gurrola, L. D., Keller, E.A., and Brandt, T. R., in press, Geologic map of the Santa Barbara coastal plain area, Santa Barbara County, California: U.S. Geological Survey Scientific Investigations Map 3001, 62 ms. p., scale 1:24,000.

Muhs, D. R., Rockwell, T. K., and Kennedy, G. L., 1992, Late Quaternary uplift rates of marine terraces on the Pacific coasts of North America, southern Oregon to Baja California Sur: Quaternary International, v. 15-16, p. 121-133.

Muir, K.S., 1968, Ground-water reconnaissance of the Santa Barbara-Montecito area, Santa Barbara County, California: U.S. Geological Survey Water-Supply Paper 1859A, 28 p. 
Namson, J., and Davis, T.L., 1988, Structural transect of the western Transverse Ranges, California: Implications for lithospheric kinematics and seismic risk evaluation: Geology, v. 16, p. 675-679.

Natland, M.L., 1952, Pleistocene and Pliocene stratigraphy of southern California: Los Angeles, University of California, Ph.D. thesis, 165 p.

Olson, D.J., 1982, Surface and subsurface geology of the Santa Barbara-Goleta metropolitan area, Santa Barbara County, California: Corvallis, Oregon, Oregon State University, M.S. thesis, 71 p.

Patterson, R.T., Brunner, C.A., Capo, Rosemary, and Dahl, Jeremy, 1990, A paleoenvironmental study of early to middle Pleistocene foraminifera of the Santa Barbara Formation at Santa Barbara, California: Journal of Paleontology, v. 64, no. 1, p. 1-25.

Prothero, D.R., 2001, Magnetostratigraphic tests of sequence stratigraphic correlations from the Southern California Paleogene: Journal of Sedimentary Research, v. 71, no. 4, p. 526-536.

Rigsby, C.A., 1998, Paleogeography of the Western Transverse Range Province, California-New evidence for the late Oligocene and early Miocene Vaqueros Formation: U.S. Geological Survey Bulletin 1995-T, p. T1-T18.

Rockwell, T.K., Nolan, Jeff, Johnson, D.L., and Patterson, R.H., 1992, Ages and deformation of marine terraces between Point Conception and Gaviota, western Transverse Ranges, California, in Quaternary coasts of the United States: Marine and Lacustrine systems: Society of Economic Paleontologists and Mineralogists Special Publication 48, p. 333-341.

Stanley, R.G., Valin, Z.C., and Pawlewicz, 1992, Rock-Eval pyrolysis and vitrinite reflectance results from outcrop samples of the Rincon Shale (lower Miocene) collected at the Tajiguas Landfill, Santa Barbara County, California: U.S. Geological Survey Open-File Report 92-571, 27 p.

Stanley, R.G., Cotton, M.L., Bukry, David, Filewicz, M.V., Valin, Z.C., and Vork, D.R., 1994, Stratigraphic revelations regarding the Rincon Shale (lower Miocene) in the Santa Barbara coastal area, California [abs.]: American Association of Petroleum Geologists Bulletin, v. 78, no. 4, p. 675-676. 
Stanley, R.G., Johnson, S.Y., Swisher, C.C., III, Mason, M.A., Obradovich, J.D., Cotton, M.L., Filewicz, M.V., and Vork, D.R., 1996, Age of the Lospe Formation (early Miocene) and origin of the Santa Maria basin, California: U.S. Geological Survey Bulletin 1995-M, p. M1-M37.

Tennyson, M.E., and Isaacs, C.M., 2001, Geologic setting and petroleum geology of the Santa Maria and Santa Barbara basins, coastal California, in Isaacs, C.M., and Rullkotter, Jurgen, eds., The Monterey Formation - From rocks to molecules: Columbia University Press, New York, p. 206-229.

Turner, D.L., 1970, Potassium-argon dating of Pacific coast Miocene foraminiferal stages, in Bandy, O.L., ed., Radiometric dating and paleontologic zonation: Geological Society of America Special Paper 124, p. 91-129.

Upson, J.E., 1951, Geology and ground-water resources of the south-coast basins of Santa Barbara County, California: U.S. Geological Survey Water-Supply Paper 1108, 144 p.

U.S. Geological Survey Geologic Names Committee, 2007, Divisions of geologic timemajor chronostratigraphic and geochronologic units: U.S. Geological Survey Fact Sheet 2007-3015.

Valentine, J.W., 1961, Paleoecologic molluscan geography of the California Pleistocene: University of California Publications in Geological Sciences, v. 34, no. 7, p. 309-442.

Weaver, D.W., and Kleinpell, R.M., 1963, Oligocene biostratigraphy of the Santa Barbara embayment, California, Part II, Mollusks from the Turritella variata zone: University of California Publications in the Geological Sciences, v. 43, p. 81-118.

Wehmiller, J.F., 1992, Aminostratigraphy of southern California Quaternary marine terraces, in Fletcher, C.H., and Wehmiller, J.F., eds., Quaternary coasts of the United States: marine and lacustrine systems: SEPM (Society for Sedimentary Geology) Special Publication 48, p. 317-321.

Williams, Howell, Turner, F.J., and Gilbert, C.M., 1982, Petrography: an introduction to the study of rocks in thin sections ( $2 \mathrm{~d}$ ed.): San Francisco, W.H. Freeman and Company, $626 \mathrm{p}$.

Willis, Bailey, 1925, A study of the Santa Barbara earthquake of June 29, 1925 : Seismological Society of America Bulletin, v. 15, n. 4, p. 255-278, fault map.

Wright, Robert H., 1972, Late Pleistocene marine fauna, Goleta, California: Journal of Paleontology, v. 46, no. 5, p. 688-695. 
Yerkes, R.F., and Lee, W.H.K., 1987, Late Quaternary deformation in the western Transverse Ranges, in Morton, D.M., and Yerkes, R.F., eds., Recent reverse faulting in the Transverse Ranges, California: U.S. Geological Survey Professional Paper 1339, p. 71-82.

Yerkes, R.F., Sarna-Wojcicki, A.M., and Lajoie, K.R., 1987, Geology and Quaternary deformation of the Ventura area, in Morton, D.M., and Yerkes, R.F., eds., Recent reverse faulting in the Transverse Ranges, California: U.S. Geological Survey Professional Paper 1339, p. 169-178. 